\title{
Effects of dietary zinc source on the metabolic and immunological response to lipopolysaccharide in lactating Holstein dairy cows
}

\author{
E. A. Horst, ${ }^{1}$ E. J. Mayorga, ${ }^{1}$ M. Al-Qaisi, ${ }^{1}$ M. A. Abeyta, ${ }^{1}$ B. M. Goetz, ${ }^{1}$ H. A. Ramirez Ramirez, ${ }^{1} \odot$ \\ D. H. Kleinschmit, ${ }^{2}$ and L. H. Baumgard ${ }^{1 *}$ (D) \\ ${ }^{1}$ Department of Animal Science, lowa State University, Ames 50011 \\ ${ }^{2}$ Zinpro Corporation, Eden Prairie, MN 55344
}

\section{ABSTRACT}

The objectives of this study were to evaluate the effects of replacing $40 \mathrm{mg} / \mathrm{kg}$ of $\mathrm{Zn}$ from $\mathrm{Zn}$ sulfate (control; CON) with Zn AA complex (AvZn) on metabolism and immunological responses following an intravenous lipopolysaccharide (LPS) challenge in lactating cows. Cows were randomly assigned to 1 of 4 treatments: (1) pair-fed (PF) control (PF-CON; 5 $\mathrm{mL}$ of saline; $\mathrm{n}=5)$, (2) PF AvZn (PF-AvZn; $5 \mathrm{~mL}$ of saline; $\mathrm{n}=5$ ), (3) LPS euglycemic clamp control (LPSCON; $0.375 \mu \mathrm{g}$ of LPS/kg of BW; $\mathrm{n}=5$ ), and (4) LPS euglycemic clamp AvZn (LPS-AvZn; $0.375 \mu \mathrm{g}$ of LPS/ $\mathrm{kg}$ of $\mathrm{BW} ; \mathrm{n}=5)$. Cows were enrolled in 3 experimental periods $(\mathrm{P})$. During period 1 (3 d), cows received their respective dietary treatments and baseline data were obtained. During period 2 (P2; 2 d), a 12-h LPS euglycemic clamp was conducted or cows were PF to their respective dietary counterparts. During period 3 (P3; 3 d), cows received their dietary treatment and consumed feed ad libitum. Mild hyperthermia $\left(1^{\circ} \mathrm{C}\right)$ was observed in LPS cows at $3 \mathrm{~h}$ postbolus. Throughout P2, the rectal temperature of LPS-AvZn cows was decreased $\left(0.3^{\circ} \mathrm{C}\right)$ relative to LPS-CON cows. Administrating LPS decreased dry matter intake $(47 \%)$ during P2, and by experimental design the pattern was similar in $\mathrm{PF}$ cohorts. During P3, dry matter intake from LPS cows remained decreased (15\%) relative to PF cows. Milk yield from LPS cows decreased (54\%) during P2 relative to PF cows, but it was similar during P3. During $\mathrm{P} 2$, somatic cell count increased 3-fold in LPS cows relative to PF controls. Dietary AvZn tended to decrease somatic cell count $(70 \%)$ during P3 relative to LPS-CON cows. Insulin increased 7 -fold in LPS cows at $12 \mathrm{~h}$ postbolus and remained increased (4-fold) for the duration of P2. Circulating glucagon from LPS cows increased (65\%) during P2, and supplementing AvZn

Received May 29, 2019.

Accepted August 25, 2019.

*Corresponding author: baumgard@iastate.edu blunted the increase (30\% relative to LPS-CON). During P2, circulating cortisol increased 7-fold post-LPS infusion relative to $\mathrm{PF}$ cows, and supplementing AvZn decreased cortisol (58\%) from 6 to $48 \mathrm{~h}$ postbolus relative to LPS-CON cows. Administrating LPS increased circulating LPS-binding protein and serum amyloid A (3- and 9-fold, respectively) relative to PF cows. Compared with LPS-CON, LPS-AvZn cows had increased circulating serum amyloid A (38\%) $24 \mathrm{~h}$ postbolus. The 12-h total glucose deficit was 36 and 1,606 g for the PF and LPS treatments, respectively, but was not influenced by Zn source. In summary, replacing a portion of the Zn sulfate with Zn AA complex appeared to reduce the inflammatory response but had no effect on the glucose deficit.

Key words: leukocyte, cortisol, somatic cell count

\section{INTRODUCTION}

Uterine, mammary, and intestinal epithelial integrity can become compromised due to a variety of stressors (Khafipour et al., 2009; Kvidera et al., 2017c; Koch et al., 2019), and hyperpermeability of these barriers permits pathogen infiltration and, ultimately, immune stimulation (van Miert and Frens, 1968). Regardless of the pathogen's origin, a robust and transient immune response is imperative to successful pathogen clearance, resolution of inflammation, and return to optimal production (i.e., milk production, growth, and reproduction; Bertoni et al., 2008; Bradford et al., 2015; Trevisi and Minuti, 2018). Mounting a successful immune response is dependent on effective leukocyte communication (cytokine and chemokine production), extravasation, cellular function (i.e., intracellular killing, reactive oxygen species production, cytokine production), and the elimination of cell debris and harmful byproducts. The energetic costs of initiating an immune response are substantial (Johnson, 2012), and this is particularly true for glucose (Kvidera et al., 2016, 2017a,b; Horst et al., 2018). Therefore, dietary strategies capable of improving barrier integrity and immune responses are 
of practical and economic interest, particularly in lactating dairy cows because glucose is critical for copious milk synthesis (Baumgard et al., 2017).

Zinc plays a pivotal role as a structural, catalytic, and signaling component. Although it has multiple responsibilities, its immunomodulatory effects have received considerable attention (Osorio et al., 2016; Wessels et al., 2017). Zinc is required for proper epithelial barrier function and regulates damaged epithelium regeneration (Alam et al., 1994). Furthermore, leukocyte formation, maturation and differentiation, activation, cellular function, and apoptotic rate (among others) are $\mathrm{Zn}$ dependent and are largely influenced by changes in Zn homeostasis (Haase and Rink, 2014; Wessels and Cousins, 2015). Thus, providing dietary sources of $\mathrm{Zn}$ (with optimal bioavailability) may benefit leukocyte function and communication and consequently could influence the overall energetic cost of immunoactivation. Research suggests that organic trace minerals improve bioavailability and mineral retention compared with inorganic forms (Spears, 1989). Further, altered cytokine and acute phase protein (APP) production have been observed with supplemental complexed Zn in ruminants and monogastrics compared with inorganic forms (Abuajamieh et al., 2016; Mayorga et al., 2018).

We hypothesized that feeding complexed $\mathrm{Zn}$ would improve the immune response to an LPS challenge and alter leukocyte glucose consumption. Therefore, the objectives of this study were to evaluate the effects of supplemental Zn AA complex on productivity, metabolism, glucose consumption, and circulating leukocyte dynamics and function in an acute and intensely activated immune system via the LPS euglycemic clamp technique.

\section{MATERIALS AND METHODS}

\section{Animals and Experimental Design}

All procedures were approved by the Iowa State University Institutional Animal Care and Use Committee. Twenty nonpregnant lactating Holstein cows (715 \pm $19 \mathrm{~kg}$ of BW; $284 \pm 29$ DIM; parity $2 \pm 0.2)$ were used in an experiment conducted in 2 replications (10 cows/replicate). Cows were randomly assigned to 1 of 2 dietary treatments: (1) control (CON; $64 \mathrm{mg} / \mathrm{kg}$ of supplemental $\mathrm{Zn}$ from $\mathrm{ZnSO}_{4}$ ) or (2) replacement of 40 ppm of $\mathrm{ZnSO}_{4}$ with Zn AA complex (AvZn; Availa-Zn, Zinpro Corporation, Eden Prairie, MN). Actual dietary Zn concentrations (Dairyland Laboratories Inc., Arcadia, WI) were 111 and $112 \mathrm{mg} / \mathrm{kg}$ for the CON and AvZn diets, respectively. Before the start of the study (i.e., before cows were moved into individual pens), cows were fed their respective diets for $42 \mathrm{~d}$ at the
Iowa State University Dairy Farm (Ames). After the initial feeding phase, cows were moved to individual box stalls $(4.57 \times 4.57 \mathrm{~m})$ at the Iowa State University Dairy. Cows were allowed $4 \mathrm{~d}$ to acclimate to housing conditions; during this time they were implanted with bilateral jugular catheters as previously described (Baumgard et al., 2011). The trial consisted of 3 experimental periods. Period 1 (P1) lasted $3 \mathrm{~d}$ and served as the baseline (data generated for covariate analysis) for period 2 (P2) and period 3 (P3). At the initiation of P2, which lasted $48 \mathrm{~h}$, animals either experienced a 12-h LPS euglycemic clamp as previously described (Kvidera et al., 2016, 2017a; Horst et al., 2018) or were pair-fed $(\mathbf{P F})$ to their respective dietary counterparts for the entire $48 \mathrm{~h}$ to eliminate the confounding effects of dissimilar nutrient intake. Dietary and challenged combinations resulted in 4 treatments: (1) PF control $\operatorname{diet}(\mathbf{P F}-\mathbf{C O N} ; 5 \mathrm{~mL}$ of sterile saline with $\mathrm{CON}$ diet; $\mathrm{n}$ $=5)$, (2) PF Availa-Zn diet (PF-AvZn; 5 mL of sterile saline with AvZn diet; $\mathrm{n}=5$ ), (3) LPS euglycemic clamp control diet (LPS-CON; $0.375 \mu \mathrm{g}$ of LPS/kg of BW with CON diet; $\mathrm{n}=5$ ), and (4) LPS euglycemic clamp Availa-Zn diet (LPS-AvZn; $0.375 \mu \mathrm{g}$ of LPS $/ \mathrm{kg}$ of BW with AvZn diet; $\mathrm{n}=5$ ). During P2, cows receiving LPS were allowed to eat ad libitum, but the salineinfused cows were pair-fed to their dietary counterparts to eliminate the confounding effects of dissimilar feed intake. For pair-feeding calculations, feed intake was averaged for each cow and used as a baseline. During $\mathrm{P} 2$, the decrease in feed intake in LPS-CON and LPSAvZn cows was calculated every day as a percentage of feed intake reduction during $\mathrm{P} 1$. The percentage of feed intake reduction was averaged for all cows in the LPSCON and LPS-AvZn treatments on the $2 \mathrm{~d}$ of P2 and applied individually to the baseline of each cow in the PF-CON and PF-AvZn treatments. During P3 (3 d), all animals continued to receive their dietary treatment but were allowed to consume feed ad libitum.

All cows were fed a diet formulated to meet or exceed the predicted requirements of energy, protein, minerals, and vitamins (NRC, 2001; Tables 1 and 2). Reduced feed intake in LPS-treated cows during P2 was determined as a percentage of their mean daily ad libitum intake during P1. Throughout the experiment, PF cows lagged $13 \mathrm{~d}$ behind LPS-infused cows to allow for pair-feeding calculations as we have previously described (Baumgard et al., 2011). To more accurately mirror the altered feed intake pattern observed in LPSadministered cows, the amount of feed offered to the PF cows was separated into 3 portions: $10 \%$ at $1200 \mathrm{~h}$, $30 \%$ at $1800 \mathrm{~h}$, and $60 \%$ at $0000 \mathrm{~h}$ on $\mathrm{d} 1$ of P2. On d 2 of $\mathrm{P} 2$ the feed was provided as 2 equal meals at 0600 and $1800 \mathrm{~h}$. Cows were milked 4 times daily (0000, 0600, 1200, and $1800 \mathrm{~h}$ ), and yield was recorded. A 
sample for composition analysis was obtained at each milking. Samples were stored at $4^{\circ} \mathrm{C}$ with a preservative (bronopol tablet; D and F Control System, San Ramon, CA) until analysis by Dairy Lab Services (Dubuque, IA) using AOAC-approved infrared analysis equipment and procedures (AOAC International, 1995). Rectal temperature $(\mathbf{T r})$ and respiration rate $(\mathbf{R R})$ were recorded after each milking. Rectal temperature was measured using a digital thermometer (GLA M700 digital thermometer, GLA Agricultural Electronics, San Luis Obispo, CA). Respiration rate was measured as flank movements during a 15-s interval and later transformed to breaths per minute.

Table 1. Ingredient and analyzed chemical composition (\% of DM unless noted) of the $\operatorname{diet}^{1}$

\begin{tabular}{|c|c|}
\hline Item & Value \\
\hline \multicolumn{2}{|l|}{ Ingredient } \\
\hline Corn silage & 26.5 \\
\hline Ground corn & 25.7 \\
\hline Alfalfa hay & 19.8 \\
\hline Corn gluten feed & 8.8 \\
\hline Expeller soybean $^{2}$ & 4.5 \\
\hline Soybean meal & 4.5 \\
\hline Mineral mix & 4.2 \\
\hline Whole cottonseed & 3.5 \\
\hline Molasses supplement $^{3}$ & 1.7 \\
\hline Bypass fat ${ }^{4}$ & 0.8 \\
\hline \multicolumn{2}{|l|}{ Chemical analysis } \\
\hline $\mathrm{DM}(\%)$ & 47.5 \\
\hline Starch & 25.5 \\
\hline $\mathrm{CP}$ & 16.7 \\
\hline $\mathrm{NDF}$ & 32.3 \\
\hline $\mathrm{ADF}$ & 21.8 \\
\hline Ether extract & 4.83 \\
\hline $\mathrm{Ca}$ & 0.96 \\
\hline $\mathrm{P}$ & 0.43 \\
\hline $\mathrm{S}$ & 0.23 \\
\hline $\mathrm{K}$ & 1.41 \\
\hline $\mathrm{Na}$ & 0.48 \\
\hline $\mathrm{Cl}$ & 0.66 \\
\hline $\mathrm{NE}_{\mathrm{L}}(\mathrm{Mcal} / \mathrm{kg}$ of $\mathrm{DM})$ & 1.62 \\
\hline Vitamin A (IU/kg of DM) & $6,733.3$ \\
\hline Vitamin D (IU/kg of DM) & 636.3 \\
\hline Vitamin E (IU/kg of DM) & 18.7 \\
\hline
\end{tabular}

${ }^{1}$ Values represent an average of ration nutrient summary reports collected throughout the trial. Average values between both diets containing dietary treatments of $64 \mathrm{mg} / \mathrm{kg} \mathrm{Zn}$ from $\mathrm{ZnSO}_{4}$ (control diet) or $40 \mathrm{mg} / \mathrm{kg}$ Zn from Availa-Zn (Zinpro Corporation, Eden Prairie, MN) plus $24 \mathrm{mg} / \mathrm{kg} \mathrm{Zn}$ from $\mathrm{ZnSO}_{4}$ (AvZn diet). All diets contained $40 \mathrm{mg} / \mathrm{kg}$ Mn from Mn sulfate, $6.5 \mathrm{mg} / \mathrm{kg}$ Mn from Availa-Mn (manganese AA complex; Zinpro Corporation), $10.1 \mathrm{mg} / \mathrm{kg} \mathrm{Cu}$ from copper sulfate, $4.1 \mathrm{ppm}$ of $\mathrm{Cu}$ from Availa-Cu (copper AA complex; Zinpro Corporation), $0.79 \mathrm{mg} / \mathrm{kg}$ Co from Copro (cobalt glucoheptonate; Zinpro Corporation), $0.8 \mathrm{mg} / \mathrm{kg}$ I from ethylenediamine dihydroiodide, and $0.3 \mathrm{mg} / \mathrm{kg}$ Se, with $50 \%$ from sodium selenite and $50 \%$ from selenium yeast. Analyzed Zn concentrations were 111 and $112 \mathrm{mg} / \mathrm{kg}$ for the control and AvZn diets, respectively.

${ }^{2}$ Mechanically procecessed soybean meal (Dairy Nutrition Plus, Ralston, IA).

${ }^{3}$ Quality Liquid Feeds (Dodgeville, WI).

${ }^{4}$ MagnaPalm (Energy Feeds International, Lago Vista, TX).
Table 2. Ingredients and composition (\% of DM) of the vitamin and mineral mix for the $\operatorname{diets}^{1}$

\begin{tabular}{|c|c|c|}
\hline \multirow[b]{2}{*}{ Ingredient } & \multicolumn{2}{|c|}{$\operatorname{Diet}^{2}$} \\
\hline & Control & AvZn \\
\hline Calcium carbonate & 28.78 & 28.70 \\
\hline Sodium carbonate & 20.50 & 20.50 \\
\hline Blood meal & 20.00 & 20.00 \\
\hline Salt & 9.59 & 9.59 \\
\hline Magnesium oxide & 4.53 & 4.53 \\
\hline Urea & 4.01 & 4.01 \\
\hline Dried distillers grains with solubles & 3.05 & 2.57 \\
\hline Potassium chloride & 2.40 & 2.40 \\
\hline Yeast culture $^{3}$ & 1.61 & 1.61 \\
\hline Liquid methionine hydroxy analog & 1.19 & 1.19 \\
\hline Rumen-protected methionine $^{4}$ & 1.02 & 1.02 \\
\hline Mineral oil & 1.00 & 1.00 \\
\hline Availa-Zn $120^{5}$ & 0.00 & 0.83 \\
\hline Zinc sulfate & 0.45 & 0.17 \\
\hline Manganese sulfate & 0.31 & 0.31 \\
\hline Selenium premix $0.16 \%$ & 0.26 & 0.26 \\
\hline Selenium yeast 2000 & 0.21 & 0.21 \\
\hline Availa-Mn $80^{5}$ & 0.20 & 0.20 \\
\hline Vitamin E 50\% & 0.19 & 0.19 \\
\hline Rumensin $90.7^{6}$ & 0.18 & 0.18 \\
\hline Availa- $\mathrm{Cu} 100^{5}$ & 0.10 & 0.10 \\
\hline Dairy trace mineral mix & 0.10 & 0.10 \\
\hline Copper sulfate & 0.10 & 0.10 \\
\hline Biotin $2 \%$ & 0.09 & 0.09 \\
\hline Copro $25^{5}$ & 0.08 & 0.08 \\
\hline Vitamin A 650 kIU & 0.05 & 0.05 \\
\hline Vitamin $\mathrm{D}_{3} 500 \mathrm{kIU}$ & 0.01 & 0.01 \\
\hline Ethylenediamine dihydroiodide- $99 \%$ & 0.002 & 0.002 \\
\hline
\end{tabular}

${ }^{1}$ Average nutrient levels were as follows. Control diet: $30.6 \% \mathrm{CP}$, $11.33 \% \mathrm{Ca}, 0.06 \% \mathrm{P}, 2.62 \% \mathrm{Mg}, 1.35 \% \mathrm{~K}, 0.50 \% \mathrm{~S}, 19.6 \mathrm{mg} / \mathrm{kg}$ Co from Copro 25 (Zinpro Corporation, Eden Prairie, MN), $19.6 \mathrm{mg} / \mathrm{kg}$ Co total, $101 \mathrm{mg} / \mathrm{kg} \mathrm{Cu}$ from Availa-Cu 100 (Zinpro Corporation), $351 \mathrm{mg} / \mathrm{kg} \mathrm{Cu}$ total, $19.6 \mathrm{mg} / \mathrm{kg}$ I total, $160.7 \mathrm{mg} / \mathrm{kg}$ Mn from AvailaMn 80 (Zinpro Corporation), 1,152 mg/kg Mn total, $4.22 \mathrm{mg} / \mathrm{kg} \mathrm{Se}$ from selenium yeast, $8.43 \mathrm{mg} / \mathrm{kg}$ Se total, $0 \mathrm{mg} / \mathrm{kg} \mathrm{Zn}$ from Availa-Zn (Zinpro Corporation), $1,588.68 \mathrm{mg} / \mathrm{kg} \mathrm{Zn}$ total, $17.71 \mathrm{mg} / \mathrm{kg}$ Biotin (DSM Nutritional Products, Ames, IA), 33,634 $\mathrm{kIU} / \mathrm{kg}$ vitamin A, $31.79 \mathrm{kIU} / \mathrm{kg}$ vitamin $\mathrm{D}_{3}, 937 \mathrm{IU} / \mathrm{kg}$ vitamin $\mathrm{E}$, and $0.321 \mathrm{~g} / \mathrm{kg} \mathrm{mo}-$ nensin. AvZn diet: $30.7 \%$ CP, $11.33 \% \mathrm{Ca}, 0.06 \% \mathrm{P}, 2.62 \% \mathrm{Mg}, 1.35 \%$ $\mathrm{K}, 0.47 \% \mathrm{~S}, 19.6 \mathrm{mg} / \mathrm{kg}$ Co from Copro $25,19.6 \mathrm{mg} / \mathrm{kg}$ Co total, 101 $\mathrm{mg} / \mathrm{kg} \mathrm{Cu}$ from Availa-Cu 100, $351 \mathrm{mg} / \mathrm{kg} \mathrm{Cu}$ total, $19.6 \mathrm{mg} / \mathrm{kg} \mathrm{I}$ total, $160.7 \mathrm{mg} / \mathrm{kg}$ Mn from Availa-Mn, $1,152 \mathrm{mg} / \mathrm{kg} \mathrm{Mn}$ total, 4.22 $\mathrm{mg} / \mathrm{kg}$ selenium yeast, $8.43 \mathrm{mg} / \mathrm{kg}$ Se total, $1,000 \mathrm{mg} / \mathrm{kg} \mathrm{Zn}$ from Availa-Zn, 1,588.68 mg/kg Zn total, $17.71 \mathrm{mg} / \mathrm{kg}$ Biotin, 33,634 kIU/ $\mathrm{kg}$ vitamin $\mathrm{A}, 31.79 \mathrm{kIU} / \mathrm{kg}$ vitamin $\mathrm{D}_{3}, 937 \mathrm{IU} / \mathrm{kg}$ vitamin $\mathrm{E}$, and $0.321 \mathrm{~g} / \mathrm{kg}$ monensin.

${ }^{2}$ Control $=64 \mathrm{mg} / \mathrm{kg} \mathrm{Zn}$ from $\mathrm{ZnSO}_{4} \cdot \mathrm{AvZn}=40 \mathrm{mg} / \mathrm{kg} \mathrm{Zn}$ from Availa-Zn plus $24 \mathrm{mg} / \mathrm{kg}$ Zn from $\mathrm{ZnSO}_{4}$.

${ }^{3}$ NutriTek (Diamond V, Cedar Rapids, IA).

${ }^{4}$ Smartamine-M (Adisseo, Alpharetta, GA).

${ }^{5}$ Availa- $\mathrm{Zn}$, Availa-Mn, and Availa- $\mathrm{Cu}=\mathrm{Zn}, \mathrm{Mn}$, and $\mathrm{Cu} \mathrm{AA}$ complexes, respectively; Copro $=$ cobalt glucoheptonate.

${ }^{6}$ Rumensin-90 (Elanco, Greenfield, IN).

To estimate the glucose requirements of an intensely activated immune system, we employed the LPS euglycemic clamp technique as recently described (Kvidera et al., 2016, 2017a; Horst et al., 2018). Selecting the LPS dose was influenced by the magnitude of hypoglycemia observed in earlier reports (Giri et al., 1990; 
Waldron et al., 2003; Waggoner et al., 2009; Kvidera et al., 2017a). Lipopolysaccharide (Escherichia coli O55:B5; Sigma-Aldrich, St. Louis, MO) was dissolved in sterile saline at a concentration of $66.6 \mu \mathrm{g} / \mathrm{mL}$ and passed through a $0.2-\mu \mathrm{m}$ sterile syringe filter (Thermo Scientific, Waltham, MA). The total volume of LPS solution administered was approximately $4 \mathrm{~mL}$ and was infused within approximately $30 \mathrm{~s}$. Maintaining the euglycemic clamp involved infusing 50\% glucose (as dextrose; VetOne, Boise, ID) intravenously at a known and adjustable rate using a modular pump (Deltec 3000, Deltec Inc., St. Paul, MN) to maintain the pre-LPS administration blood glucose concentrations.

Blood samples were obtained at $-30,-20$, and 0 min relative to LPS or saline bolus administration to establish baseline glucose levels. Each respective treatment bolus was administered immediately following the 0 -min blood sample collection. For cows receiving LPS, postbolus blood samples $(1 \mathrm{~mL})$ were collected every 10 min and immediately analyzed for glucose concentration (Truebalance glucometer; McKesson, San Francisco, CA). Glucose infusion began when blood glucose content decreased below baseline levels, and infusion rates were adjusted as necessary to maintain euglycemia ( $\pm 5 \%$ of baseline). The rate of $50 \%$ glucose infusion $(\mathrm{mL} / \mathrm{h})$ was transformed to rate of glucose infusion (ROGI; g/h). The total glucose infused for each cow was calculated using the rate of glucose infusion for each 10-min interval (72 intervals in total) according to the following equation:

$$
\sum_{i=0}^{72} \operatorname{ROGI}(\mathrm{g} / \mathrm{h})_{i} \times \frac{1 \mathrm{~h}}{60 \min } \times 10 \mathrm{~min} .
$$

Blood glucose was measured every hour in PF cows. Vital measurements ( $\mathrm{Tr}$ and $\mathrm{RR}$ ) were obtained at -0.5 and $0 \mathrm{~h}$ relative to LPS administration every $3 \mathrm{~h}$ for the first $12 \mathrm{~h}$ postbolus and every $6 \mathrm{~h}$ thereafter. Additional blood samples were collected daily at $1800 \mathrm{~h}$ during P1 from the catheter and divided equally between a tube containing $\mathrm{K}_{2}$ EDTA (BD, Franklin Lakes, NJ; for plasma collection) and an empty glass tube (for serum collection). Additional plasma and serum samples $(\sim 10$ $\mathrm{mL}$ each) were collected from all treatments at -0.5 , $-0.33,0,3,6,9,12,18,24,30,36,42$, and $48 \mathrm{~h}$ relative to bolus administration. Serum samples were allowed to clot at room temperature for $1 \mathrm{~h}$ before centrifugation. Plasma and serum were harvested following centrifugation at $1,500 \times g$ for $15 \mathrm{~min}$ at $4^{\circ} \mathrm{C}$ and were subsequently frozen at $-20^{\circ} \mathrm{C}$ until analysis.

Serum cortisol and plasma insulin, glucagon, nonesterified fatty acids (NEFA), BHB, LPS-binding protein (LBP), serum amyloid A (SAA), BUN, glucose, and lactose concentrations were determined using commercially available kits according to the manufacturers' instructions (cortisol: Enzo Life Sciences Inc., Farmingdale, NY; insulin: Mercodia AB, Uppsala, Sweden; glucagon: RD Systems Inc., Minneapolis, MN; NEFA: Wako Chemicals USA, Richmond, VA; BHB: Pointe Scientific Inc., Canton, MI; LBP: Hycult Biotech, Uden, the Netherlands; SAA: Tridelta Development Ltd., Kildare, Ireland; BUN: Teco Diagnostics, Anaheim, CA; glucose: Wako Chemicals USA; lactose: BioVision Inc., Milpitas, CA). The inter- and intra-assay coefficients of variation for cortisol, insulin, glucagon, NEFA, BHB, BUN, glucose, LBP, SAA, and lactose were 7.6 and $9.2 \%, 6.8$ and $6.0 \%, 7.7$ and $9.8 \%, 6.4$ and $2.7 \%$, 7.0 and $6.2 \%, 4.2$ and $4.5 \%, 3.3$ and $2.0 \%, 16.1$ and $6.4 \%, 12.9$ and $6.8 \%$, and 7.9 and $4.4 \%$, respectively.

Samples for complete blood count analysis were collected at $-0.5,-0.33,0,3,6,9,12,18,24,30,36,42$, and $48 \mathrm{~h}$ relative to bolus administration. A $3-\mathrm{mL}$ blood sample was obtained from the catheter and stored at $4^{\circ} \mathrm{C}$ for approximately $12 \mathrm{~h}$ before submission to the Iowa State University's Department of Veterinary Pathology for analysis. Samples for evaluating blood physiology were measured using an iSTAT hand-held machine and cartridge (CG8+; Abbott Point of Care, Princeton, NJ) and were obtained at $0,12,24$, and 48 $\mathrm{h}$ relative to bolus administration.

\section{Neutrophil Isolation and Functional Assays}

Neutrophil isolation and functional assay techniques were performed on P1 d 5 and at 12, 24, and $48 \mathrm{~h}$ relative to LPS administration using previously described methods (Kimura et al., 2014). In brief, blood samples $(32 \mathrm{~mL})$ for neutrophil isolation were collected into 50$\mathrm{mL}$ conical tubes containing acid citrate dextrose $(8$ $\mathrm{mL}$ ) and immediately transported to the laboratory for neutrophil isolation. Samples were centrifuged at 1,000 $\times g$ for $20 \mathrm{~min}$ at room temperature and the plasma, buffy coat, and upper portion of packed red blood cells were removed. The remaining red blood cells were lysed twice and neutrophils were pelleted following centrifugation at $300 \times g$ for $5 \mathrm{~min}$. Neutrophils were resuspended in phosphate-buffered saline and standardized to $5.0 \times 10^{7}$ cells $/ \mathrm{mL}$. Neutrophil function was assessed by extracellular release of myeloperoxidase (MPO) and oxidative burst (cytochrome $\mathrm{C}$ reduction).

To assess oxidative burst, $2.5 \times 10^{6}$ polymorphonuclear leukocytes (PMN) were treated with either Hanks' balanced salt solution (HBSS) or HBSS plus phorbol myristate acetate followed by treatment with cytochrome C. Cells were incubated at $39^{\circ} \mathrm{C}$ for $15 \mathrm{~min}$ and immediately read at 2 wavelengths (550 and 650 $\mathrm{nm})$ using a spectrophotometer. 
Three cell preparations were used to assess MPO activity: (1) cells were lysed by treatment with cetyltrimethylammonium bromide solution as a measure of total MPO, (2) PMN were stimulated with equal parts calcium ionophore A23187 and cytochalasin B in HBSS to assess the release of MPO with stimulation, and (3) PMN treated with HBSS alone as a measure of unstimulated MPO release. Each preparation was loaded with $1.25 \times 10^{6}$ cells in a microtiter plate and incubated at $39^{\circ} \mathrm{C}$ for $20 \mathrm{~min}$. Following incubation, $50 \mu \mathrm{L}$ of $3,3^{\prime}, 5,5^{\prime}$-tetramethylbenzidine dihydrochloride $(3.25 \mathrm{mM})$ was added per well followed promptly with $50 \mu \mathrm{L}$ of $\mathrm{H}_{2} \mathrm{O}_{2}$ per well. The reaction was stopped after a 2-min incubation with the addition of $50 \mu \mathrm{L}$ of 2 $N \mathrm{H}_{2} \mathrm{SO}_{4}$ per well. Plates were centrifuged for $1 \mathrm{~min}$ at $600 \times g$ and the supernatant was transferred to a second plate. Optical density (OD) was determined at $405 \mathrm{~nm}$ using a spectrophotometer. Percentage of MPO released from PMN was determined using the following equation:

$$
\text { exocytosis }(\%)=
$$

$(\mathrm{OD}$ of stimulated PMN/OD of lysed PMN) $\times 100$.

\section{Calculations and Statistical Analysis}

Administering LPS reduces milk yield and therefore decreases glucose utilized for milk synthesis. The decrease in milk yield allows us to estimate the amount of glucose conserved (milk glucose deficit) due to reduced feed intake alone (PF-CON and PF-AvZn cows) and decreased feed intake coupled with ostensible glucose utilization by the immune system (LPS-CON and LPS-AvZn cows). The amount of glucose utilized for milk synthesis was calculated for each milking based on Kronfeld's (1982) estimation of $72 \mathrm{~g}$ of glucose required to synthesize $1 \mathrm{~kg}$ of milk. Milk glucose output before the challenge was averaged to establish a baseline. Milk glucose utilization at both 6 and $12 \mathrm{~h}$ was subtracted from the baseline to calculate the milk glucose deficit. For PF-CON and PF-AvZn cows, milk glucose deficit was solely used to calculate total glucose deficit. For LPS-CON and LPS-AvZn cows, milk glucose deficit plus the amount of glucose infused to maintain euglycemia were combined to obtain the total glucose deficit. After cessation of the euglycemic clamp (12 h postbolus), milk glucose deficit continued to be calculated every $6 \mathrm{~h}$ until $48 \mathrm{~h}$ postbolus.

Sample size determination (5 animals/treatment) was based on previous reports and logistical constraints (Kvidera et al., 2017a; Horst et al., 2018). Each animal's respective parameter was analyzed using repeated measures with an autoregressive covariance structure for milk yield and composition and DMI and a spatial power law for Tr and RR, iSTAT, complete blood count, neutrophil assays, and blood parameters. The repeated effect was time relative to LPS administration. There were no treatment differences due to diet in any parameter during $\mathrm{P} 1$; thus, each specific variable's prebolus values (i.e., P1 average, when available) served as a covariate for analysis of P2 and P3 (each period was statistically analyzed separately). Effects of treatment, time (hours or days relative to bolus), and treatment $\times$ time interactions were assessed as a completely randomized design using PROC MIXED (SAS Institute Inc., Cary, NC). A separate analysis was used to make statistical comparisons with baseline in which the average P1 value for each parameter was included as an additional time point. Preplanned contrasts were used to estimate differences between CON- and AvZnsupplemented cows, PF- and LPS-administered cows, and LPS-CON and LPS-AvZn cows, and these multiple comparisons were not mathematically adjusted for (Rothman, 1990). Data are represented as least squares means \pm standard error of the mean and considered significant if $P \leq 0.05$ and a tendency if $0.05<P \leq$ 0.10 .

\section{RESULTS}

Mild hyperthermia $\left(1^{\circ} \mathrm{C}\right.$, relative to PF cows; $P=$ 0.02) was observed in LPS-administered cows at $3 \mathrm{~h}$ postbolus. Throughout P2, Tr of LPS-AvZn cows was decreased $\left(0.3^{\circ} \mathrm{C}\right)$ relative to that of LPS-CON cows $(P=0.01$; Figure 1A). No treatment differences were observed in Tr during P3. No treatment differences were observed in RR during P2 (data not shown). However, during P3, RR of AvZn-supplemented cows (LPS and PF) tended to be increased ( 5 breaths/min; $P=0.06$ ) from 60 to $72 \mathrm{~h}$ postbolus, whereas $\mathrm{RR}$ of CON-supplemented cows (LPS and PF) remained the same (data not shown).

Lipopolysaccharide administration decreased DMI (47\%; $P \leq 0.05)$ relative to baseline, and the pattern and extent of reduced DMI were similar for cows in the $\mathrm{PF}$ treatments by experimental design $(P>0.82$; Figure 1B). Dry matter intake increased similarly from P2 d 1 to P2 d 2 for all treatments $(P<0.01)$. During P3, DMI of LPS-administered cows remained decreased $(12 \% ; P<0.01)$ relative to PF controls. Zinc source did not have a detectable effect on DMI.

Despite similar DMI, milk yield from LPS-administered cows decreased (54\%; $P<0.01$; Figure 1C) throughout P2 and was decreased 69 and $38 \%$ on d 1 and 2 of $\mathrm{P} 2$ relative to $\mathrm{PF}$ controls, respectively ( $P$ $<0.01$ ). No dietary effect was observed on daily milk yield. When evaluated on an hourly basis during P3, 


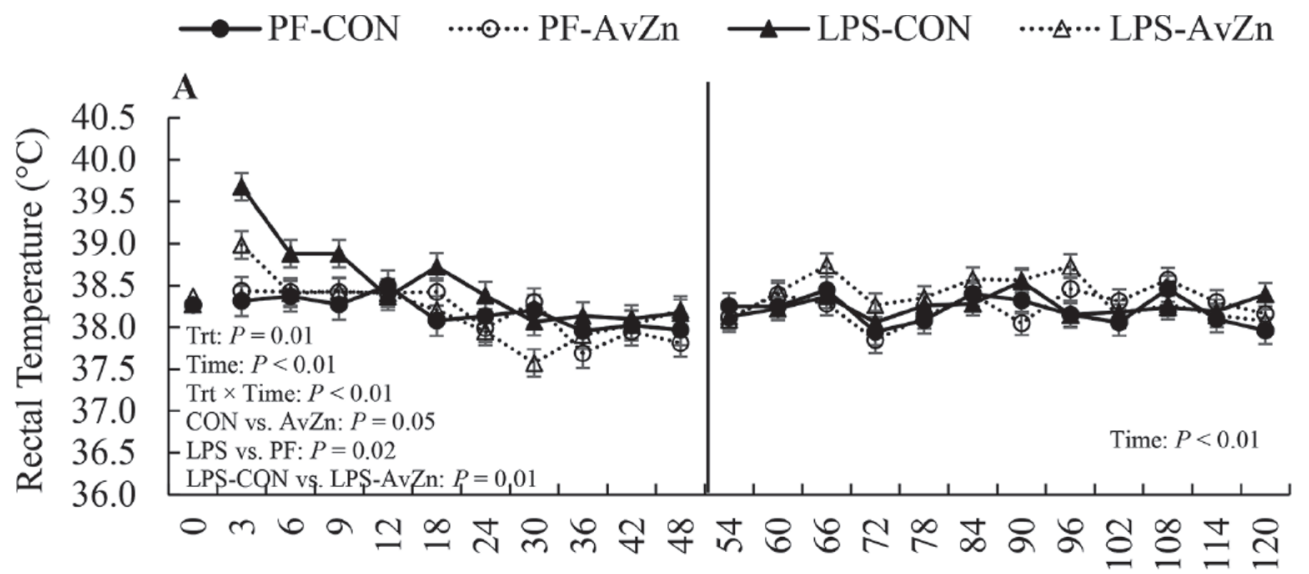

Time Relative to Bolus (h)

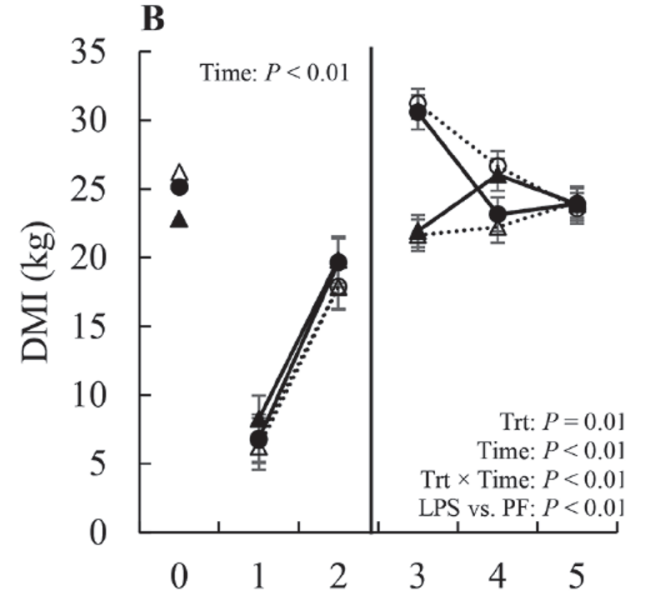

Time Relative to Bolus (d)

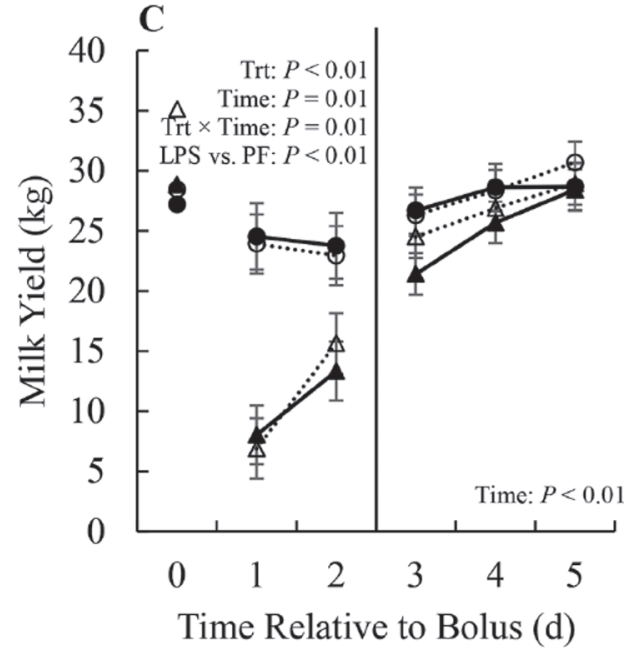

Time Relative to Bolus (d)

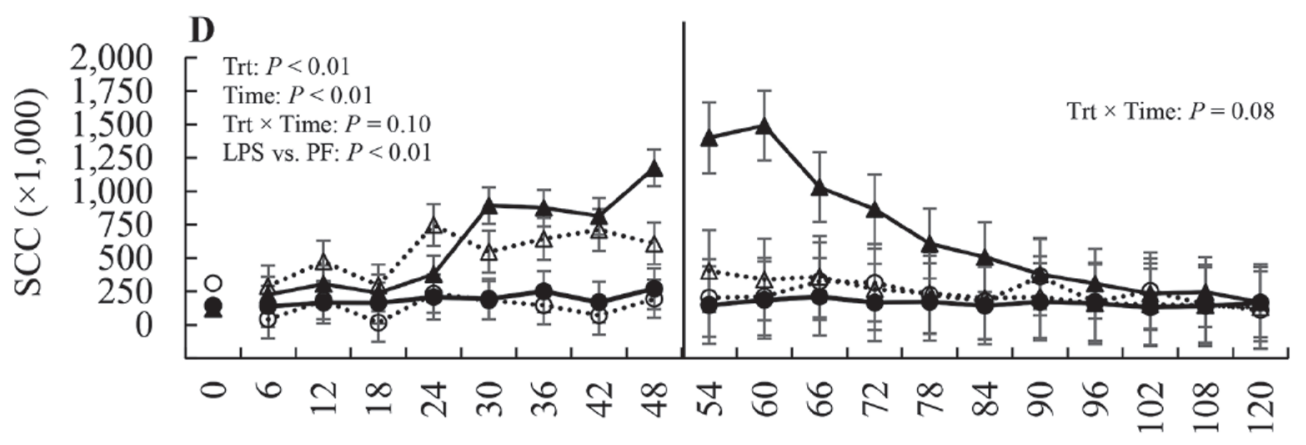

Time Relative to Bolus (h)

Figure 1. Effects of an LPS bolus or pair-feeding in dairy cows fed a control diet or a diet supplemented with a Zn AA complex on (A) rectal temperature, (B) DMI, (C) milk yield, and (D) milk SCC. Cows were randomly assigned to 1 of 2 dietary treatments: (1) control (CON; $64 \mathrm{mg} / \mathrm{kg}$ supplemental $\mathrm{Zn}$ from $\mathrm{ZnSO}_{4}$ ) or (2) replacement of $40 \mathrm{mg} / \mathrm{kg} \mathrm{ZnSO}_{4}$ with Zn AA complex (AvZn; Availa-Zn, Zinpro Corporation, Eden Prairie, MN). At the initiation of period 2 (P2), which lasted 48 h, animals either experienced a 12-h LPS euglycemic clamp as previously described (Kvidera et al., 2016, 2017a; Horst et al., 2018) or were pair-fed (PF) to their respective dietary counterparts for the entire 48 h to eliminate the confounding effects of dissimilar nutrient intake. Dietary and challenged combinations resulted in 4 treatments: (1) PF control diet $(\mathrm{PF}-\mathrm{CON} ; 5 \mathrm{~mL}$ of sterile saline with $\mathrm{CON}$ diet; $\mathrm{n}=5$ ), (2) PF Availa-Zn diet (PF-AvZn; $5 \mathrm{~mL}$ of sterile saline with AvZn diet; $\mathrm{n}=5$ ), (3) LPS euglycemic clamp control diet (LPS-CON; $0.375 \mu \mathrm{g}$ of LPS $/ \mathrm{kg}$ of BW with CON diet; $\mathrm{n}=5$ ), and (4) LPS euglycemic clamp Availa-Zn diet (LPS-AvZn; $0.375 \mu \mathrm{g}$ of LPS/kg of BW with AvZn diet; $\mathrm{n}=5$ ). Time 0 represents an average of measurements obtained during the baseline and used as a covariate for P2 and period 3 (P3) analysis. The solid line separates P2 from P3 and represents 2 separate statistical analyses. Fixed effects of treatment (Trt), time, and treatment $\times$ time were assessed as a completely randomized design using PROC MIXED of SAS (SAS Institute Inc., Cary, NC). Data are represented as LSM \pm SEM and considered significant if $P \leq 0.05$ and a tendency if $0.05<P \leq 0.10$. When $<0.10$, the $P$-value for the fixed effects and the preplanned contrasts are listed on the figure. 
milk yield from LPS-administered cows remained decreased $(8 \% ; P=0.01$; data not shown) relative to PF cows. When P3 milk yield was condensed to daily averages, no treatment differences were observed $(P>$ $0.48)$, although milk yield increased in all treatments with time $(P<0.01)$. During P2 and P3, the rate of milk yield recovery (as measured by slope) was increased in LPS-administered cows relative to PF controls $(P<$ 0.01; Table 3 ). The slope of milk yield recovery following LPS administration (for $72 \mathrm{~h}$ ) increased $(49 \%)$ in LPS-AvZn cows relative to LPS-CON cows $(P=0.05$; Table 3).

Milk urea nitrogen in LPS-infused cows gradually increased between 12 and $30 \mathrm{~h}$ postbolus, whereas it decreased in PF controls $(P=0.05$; Table 3$)$. Milk urea nitrogen of LPS-AvZn cows tended to be increased $(11 \%)$ relative to LPS-CON cows $(P=0.09$; Table 3$)$. During P3 there was a treatment $\times$ time interaction for LPS-CON cows, such that MUN content remained constant from 54 to $78 \mathrm{~h}$ postbolus, whereas in all other treatments it gradually decreased $(P<0.01$; Table 3$)$. Throughout P3, MUN from LPS-AvZn cows tended to be decreased $(10 \%)$ relative to LPS-CON cows $(P$ $=0.06$; Table 3). During P2, LPS administration decreased milk lactose content $(17 \% ; P<0.01$; Table 3$)$ and increased milk fat and protein concentrations $(32$ and $19 \%$, respectively; $P<0.01$; Table 3 ) relative to $\mathrm{PF}$ cows. Milk lactose content of all treatments increased throughout P3 ( $P=0.01$; Table 3). Overall during P3, milk fat content from LPS-administered cows remained increased $(11 \%)$ relative to $\mathrm{PF}$ controls $(P=0.04$; Table 3). Milk fat and protein content of all treatments gradually returned to baseline with time $(P<0.01)$. Other than slightly increasing MUN in LPS-AvZn cows, AvZn supplementation had little to no effect on milk composition during P2 (Table 3).

Milk SCC from LPS-administered cows tended to increase with time, whereas in $\mathrm{PF}$ cows it remained unchanged $(P=0.10$; Figure 1D). During P3, no treatment differences were observed in SCC; however, post hoc analysis revealed that SCC of LPS-AvZn cows tended to be decreased (70\%) from 54 to $78 \mathrm{~h}$ postbolus relative to LPS-CON cows $(P=0.10$; Figure 1D).

Hyperglycemia occurred in LPS-infused cows for approximately $200 \mathrm{~min}$ postbolus, after which continuous glucose infusion was necessary to maintain euglycemia (Figure 2A). Rate of glucose infusion did not differ due to dietary $\mathrm{Zn}$ source, but did increase with time $(P<$ 0.01 ; Figure 2A). For the first $70 \mathrm{~min}$ of the hyperglycemic phase, LPS-AvZn cows tended to have decreased $(19 \%)$ circulating glucose relative to LPS-CON cows $(P$ $=0.09$; Figure $2 \mathrm{~A}$ ). Relative to PF cows, the 48 -h milk glucose deficit was increased $(75 \%)$ in LPS-administered cows throughout P2 $(P<0.01$; data not shown).
Similarly, the total glucose deficit was 44 -fold more in LPS-administered cows relative to PF cows. Total glucose deficit accumulated over the $12 \mathrm{~h}$ was 5, 67, 1,500, and $1,712 \mathrm{~g}$ for PF-CON, PF-AvZn, LPS-CON, and LPS-AvZn cows, respectively (Figure 2B). Dietary Zn source did not affect the glucose deficit metrics.

For the duration of glucose infusion, circulating insulin in LPS-administered cows was 7 -fold more than that in PF controls $(P=0.05)$, and it remained increased 5 -fold after the $12 \mathrm{~h}$-infusion period $(P<0.01$; Figure $3 \mathrm{~A})$. Although not significant $(P>0.41)$, insulin concentrations were numerically decreased $(51 \%)$ in LPSAvZn cows from 3 to $12 \mathrm{~h}$ relative to LPS-CON cows (Figure 3A). Circulating glucagon in LPS-administered cows increased $(65 \%)$ throughout $\mathrm{P} 2$ relative to $\mathrm{PF}$ controls $(P<0.01$; Figure 3B). Supplementing AvZn decreased glucagon concentrations $(30 \%)$ following LPS administration relative to LPS-CON cows $(P=0.02$; Figure 3B). From 3 to $12 \mathrm{~h}$ postbolus, circulating NEFA in LPS-AvZn cows remained similar to baseline levels, whereas in all other treatments it gradually increased $(P=0.02$; Figure 3C). Throughout P2, circulating NEFA from LPS-infused cows decreased $(39 \%)$ relative to PF controls $(P=0.05$; Figure $3 \mathrm{C})$. Circulating BHB in LPS-administered cows decreased relative to the PF controls during P2 $(P<0.01$; Figure 3D). Blood urea nitrogen concentrations in LPS-infused cows increased $(29 \%)$ during $\mathrm{P} 2$ relative to PF controls $(P<0.01)$. From 12 to $24 \mathrm{~h}$ postbolus, circulating BUN from LPS treatments continued to increase, whereas in PF cows it gradually decreased $(P<0.01$; Table 4$)$. During P2, plasma lactose concentrations from LPS cows increased $(26 \%)$ relative to $\mathrm{PF}$ cows $(P=0.05$; Table 4$)$. Following LPS administration, ionized Ca markedly decreased (33\% at $12 \mathrm{~h}$ postbolus) and it gradually returned to baseline, whereas in PF controls ionized Ca levels remained similar to baseline concentrations $(P<0.01$; Figure 3E). Interestingly, ionized Ca from LPS-AvZn cows tended to be increased $(19 \%)$ relative to that from LPS-CON cows at $12 \mathrm{~h}$ postbolus $(P=0.10)$.

Circulating LBP from LPS-administered cows increased 3 -fold $(P<0.01$; Figure $4 \mathrm{~A})$ throughout P2 relative to PF controls. Similarly, circulating SAA increased in LPS-challenged cows with time, whereas in $\mathrm{PF}$ controls it remained similar to baseline (9-fold increase relative to PF; $P<0.01$; Figure 4B). At $24 \mathrm{~h}$ postbolus, circulating SAA from LPS-AvZn cows was increased $(38 \%)$ relative to LPS-CON cows $(P=0.03)$. Post hoc analysis revealed increased SAA from 12 to $24 \mathrm{~h}$ postbolus $(43 \% ; P=0.05)$ in LPS-AvZn cows relative to LPS-CON cows (Figure 4B). Administrating LPS increased circulating cortisol 7-fold throughout $\mathrm{P} 2$ relative to $\mathrm{PF}$ cows $(P<0.01$; Figure $4 \mathrm{C})$, and supplementing AvZn decreased cortisol (37\%) from 6 
HORST ET AL.

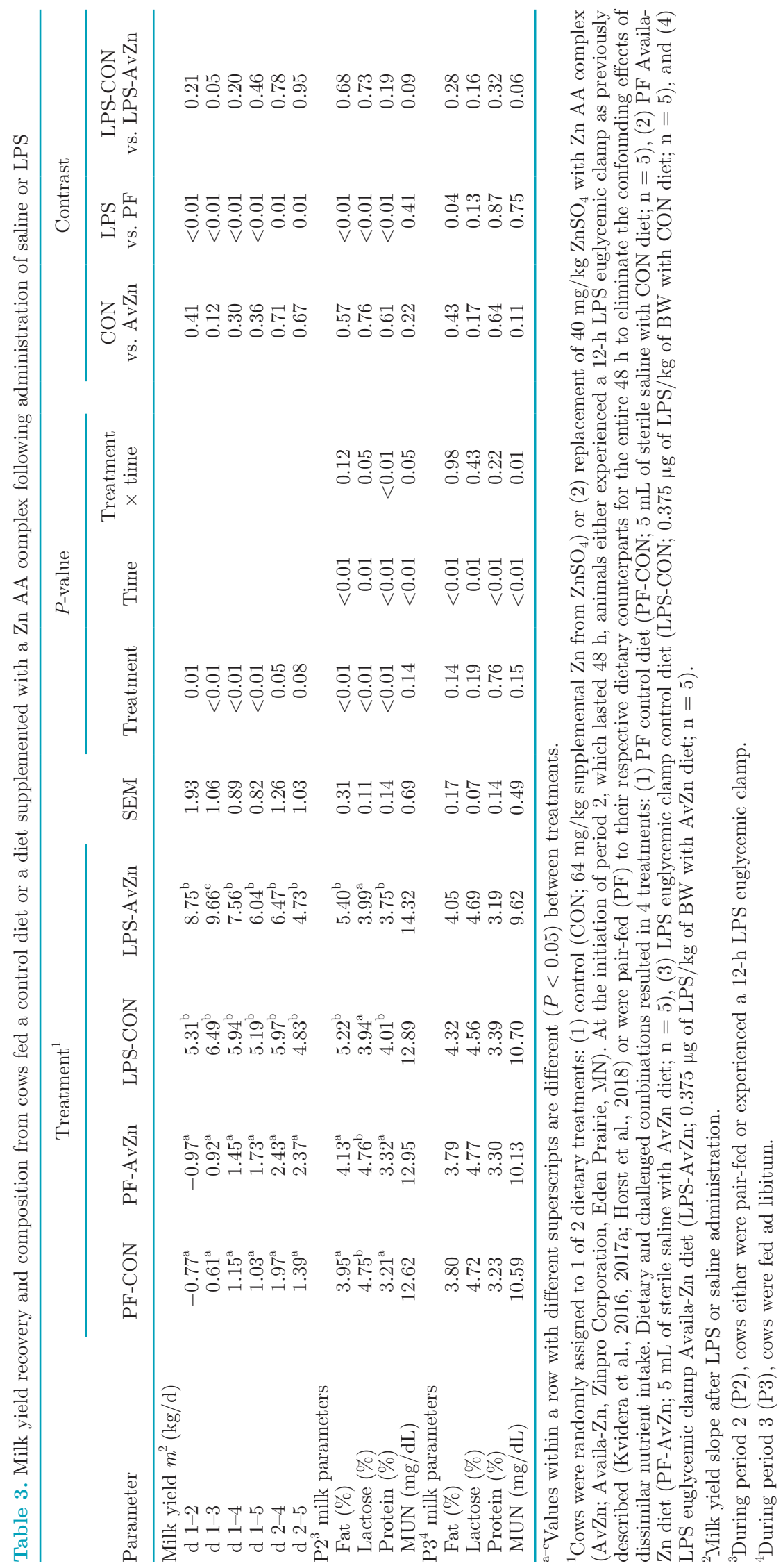


Glucose

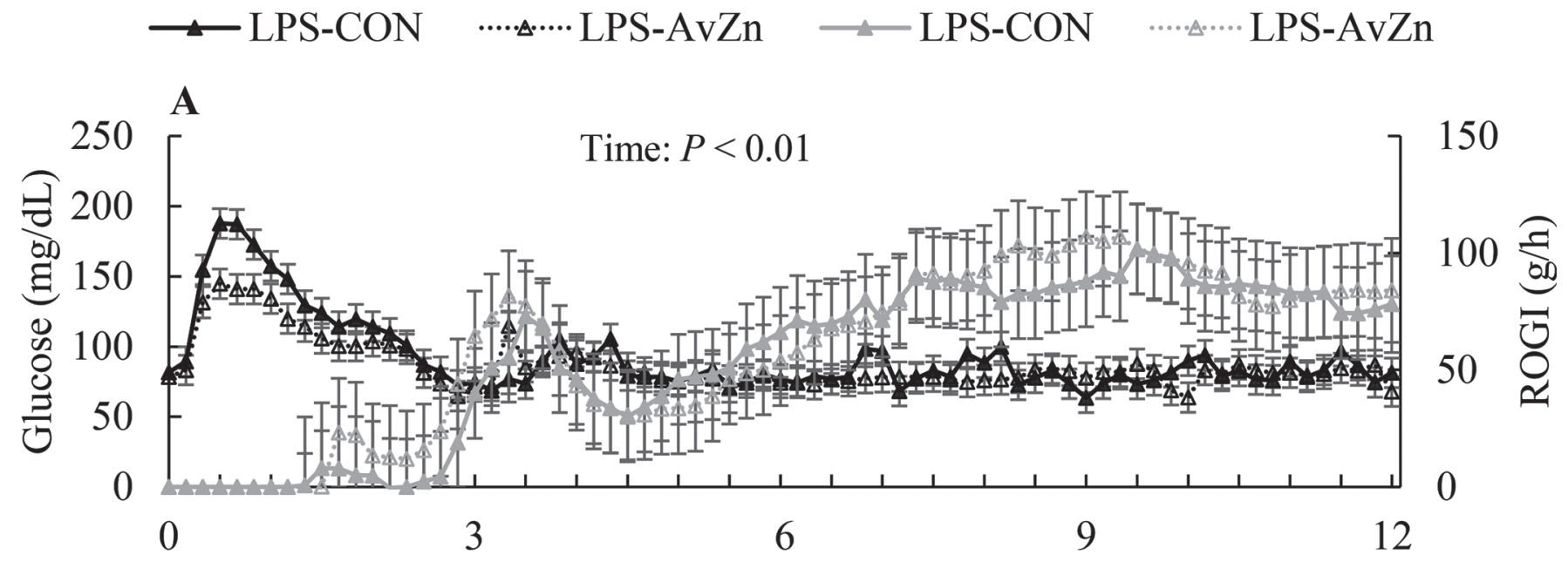

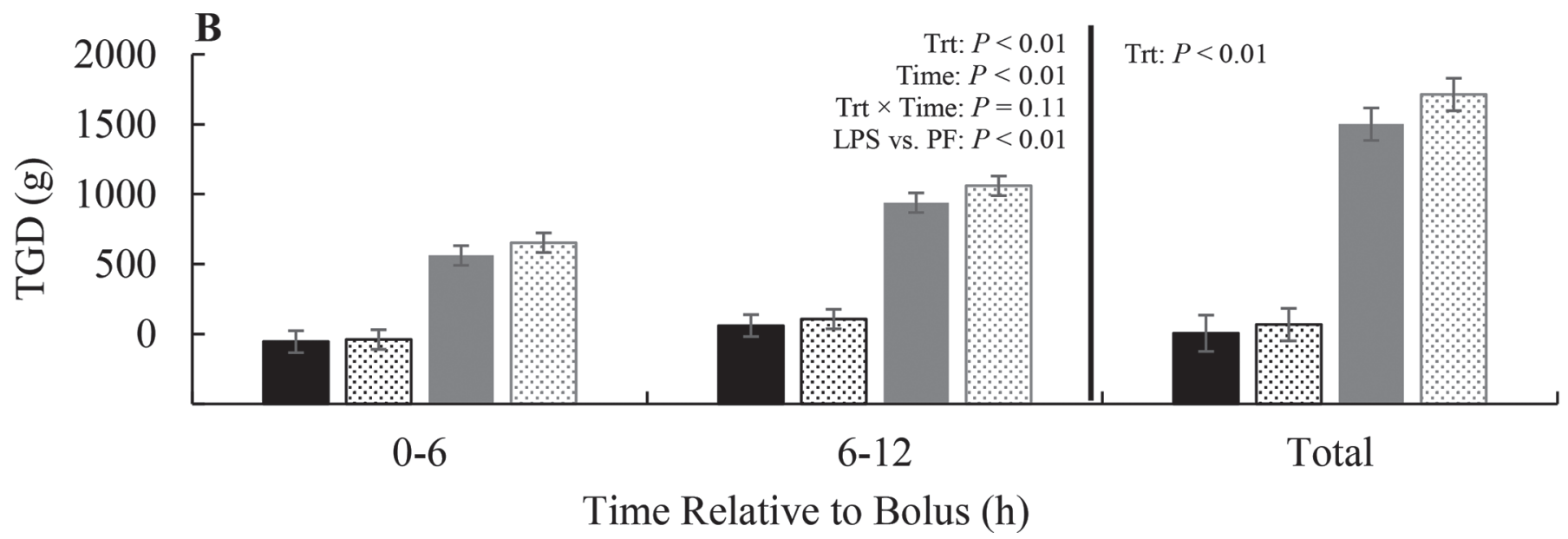

Figure 2. Effects of an LPS bolus or pair-feeding in dairy cows fed a control diet or a diet supplemented with a Zn AA complex on (A) circulating glucose and rate of glucose infusion (ROGI) and (B) milk or total glucose deficit (TGD) from 0 to $6 \mathrm{~h}$, from 6 to $12 \mathrm{~h}$, and accumulated over $12 \mathrm{~h}$. Cows were randomly assigned to 1 of 2 dietary treatments: (1) control $(\mathrm{CON} ; 64 \mathrm{mg} / \mathrm{kg}$ supplemental Zn from ZnSO 4 ) or (2) replacement of $40 \mathrm{mg} / \mathrm{kg} \mathrm{ZnSO}$ with Zn AA complex (AvZn; Availa-Zn, Zinpro Corporation, Eden Prairie, MN). At the initiation of period 2 , which lasted $48 \mathrm{~h}$, animals either experienced a 12-h LPS euglycemic clamp as previously described (Kvidera et al., 2016, 2017a; Horst et al., 2018) or were pair-fed (PF) to their respective dietary counterparts for the entire $48 \mathrm{~h}$ to eliminate the confounding effects of dissimilar nutrient intake. Dietary and challenged combinations resulted in 4 treatments: (1) PF control diet (PF-CON; $5 \mathrm{~mL}$ of sterile saline with CON diet; $\mathrm{n}=$ 5), (2) PF Availa-Zn diet (PF-AvZn; $5 \mathrm{~mL}$ of sterile saline with AvZn diet; $\mathrm{n}=5$ ), (3) LPS euglycemic clamp control diet (LPS-CON; $0.375 \mu \mathrm{g}$ of LPS $/ \mathrm{kg}$ of BW with CON diet; $\mathrm{n}=5$ ), and (4) LPS euglycemic clamp Availa-Zn diet (LPS-AvZn; $0.375 \mu \mathrm{g}$ of LPS/kg of BW with AvZn diet; $\mathrm{n}=5$ ). Fixed effects of treatment (Trt), time, and treatment $\times$ time were assessed as a completely randomized design using PROC MIXED of SAS (SAS Institute Inc., Cary, NC). Data are represented as LSM \pm SEM and considered significant if $P \leq 0.05$ and a tendency if $0.05<P \leq$ 0.10 . When $<0.10$, the $P$-value for the fixed effects and the preplanned contrasts are listed on the figure.

to $48 \mathrm{~h}$ postbolus relative to LPS-CON cows $(P=0.04$; Figure 4C).

Circulating white blood cells from LPS-infused cows were initially decreased between 3 and $12 \mathrm{~h}$ postbolus (51\%) relative to PF controls $(P<0.01$; Table 5), after which cows from the LPS treatments developed leukocytosis $(36 \%$ increase relative to PF; $P<0.01)$.
Relative to PF-CON cows, circulating white blood cell counts of PF-AvZn cows tended to be increased $(31 \%)$ at $30 \mathrm{~h}$ postbolus $(P=0.09$; Table 5$)$. Circulating neutrophils reflected a similar biphasic response $(P$ $<0.01$; Figure 5A). Patterns of circulating monocytes and lymphocytes in LPS-infused cows were comparable with white blood cell counts, although the leukopenia 

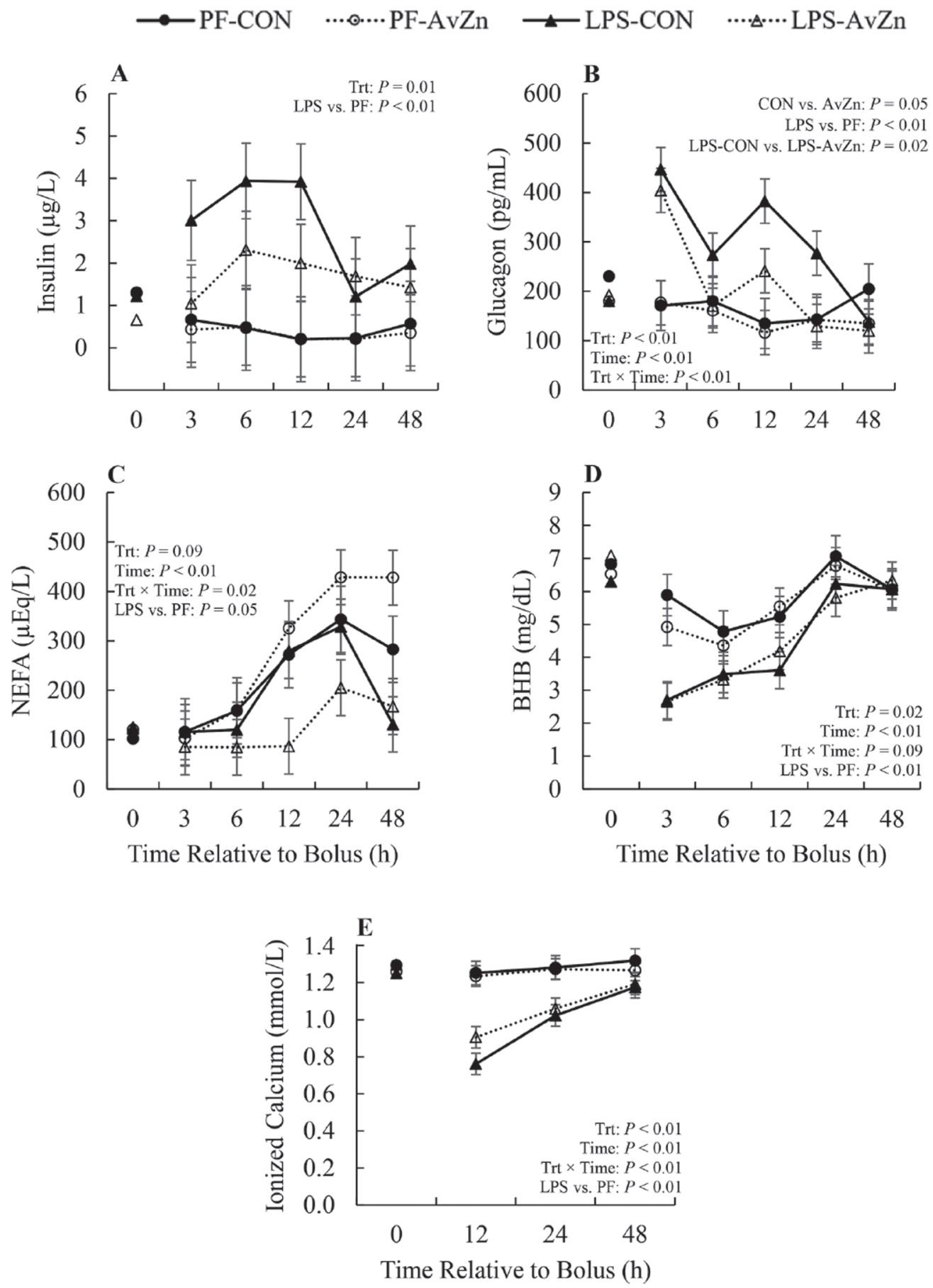

Figure 3. Effects of an LPS bolus or pair-feeding in dairy cows fed a control diet or a diet supplemented with a Zn AA complex on circulating (A) insulin, (B) glucagon, (C) nonesterified fatty acids (NEFA), (D) BHB, and (E) ionized calcium. Cows were randomly assigned to 1 of 2 dietary treatments: (1) control $\left(\mathrm{CON} ; 64 \mathrm{mg} / \mathrm{kg}\right.$ supplemental $\mathrm{Zn}$ from $\mathrm{ZnSO}_{4}$ ) or (2) replacement of $40 \mathrm{mg} / \mathrm{kg} \mathrm{ZnSO} 4$ with Zn AA complex (AvZn; Availa-Zn, Zinpro Corporation, Eden Prairie, MN). At the initiation of period 2 (P2), which lasted 48 h, animals either experienced a 12-h LPS euglycemic clamp as previously described (Kvidera et al., 2016, 2017a; Horst et al., 2018) or were pair-fed (PF) to their respective dietary counterparts for the entire $48 \mathrm{~h}$ to eliminate the confounding effects of dissimilar nutrient intake. Dietary and challenged combinations resulted in 4 treatments: (1) PF control diet (PF-CON; $5 \mathrm{~mL}$ of sterile saline with CON diet; $\mathrm{n}=5$ ), (2) PF Availa-Zn diet (PF-AvZn; 5 mL of sterile saline with AvZn diet; $\mathrm{n}=5$ ), (3) LPS euglycemic clamp control diet (LPS-CON; $0.375 \mu \mathrm{g}$ of LPS $/ \mathrm{kg}$ of BW with CON diet; $\mathrm{n}=$ 5), and (4) LPS euglycemic clamp Availa-Zn diet (LPS-AvZn; $0.375 \mu \mathrm{g}$ of LPS/kg of BW with AvZn diet; $\mathrm{n}=5$ ). Time 0 represents an average of measurements obtained during the baseline and used as a covariate for P2 and period 3 analysis. Fixed effects of treatment (Trt), time, and treatment $\times$ time were assessed as a completely randomized design using PROC MIXED of SAS (SAS Institute Inc., Cary, NC). Data are represented as LSM $\pm \mathrm{SEM}$ and considered significant if $P \leq 0.05$ and a tendency if $0.05<P \leq 0.10$. When $<0.10$, the $P$-value for the fixed effects and the preplanned contrasts are listed on the figure. 
phase was prolonged (61 and $45 \%$ decrease from 3 to $36 \mathrm{~h}$ postbolus relative to $\mathrm{PF}$ cows; $P<0.01$; Table 5). Circulating basophils in LPS cows tended to be decreased from 3 to $6 \mathrm{~h}$ and increased from 30 to $48 \mathrm{~h}$ postbolus, whereas in $\mathrm{PF}$ controls they did not change $(P=0.06$; Table 5). During P2, LPS administration decreased circulating platelets $(48 \%)$ relative to $\mathrm{PF}$ cows $(P<0.01$; Table 5$)$.

During P2, no treatment differences were observed in neutrophil oxidative burst (data not shown). However, relative to baseline, oxidative burst from LPS-AvZn cows increased (44\%) throughout P2 $(P \leq 0.05$; data not shown). Oxidative burst of LPS-CON cows tended to be increased (31\%) $48 \mathrm{~h}$ post-LPS administration relative to baseline $(P=0.07$; data not shown). Stimulated MPO activity increased similarly in all treatments during P2 (Figure 5B). In LPS-infused cows, the MPO released increased for the first $12 \mathrm{~h}$ postbolus (38\% relative to baseline; $P \leq 0.05)$ and then returned to baseline $(P<0.01$; Figure $5 \mathrm{~B})$, whereas in PF cows it remained increased throughout all of $\mathrm{P} 2(P \leq 0.05)$. Dietary Zn source had no effect on stimulated MPO release. Total MPO from LPS-infused cows (determined by cell lysis) decreased (23\% relative to PF cows) from 24 to $48 \mathrm{~h}$ postbolus, whereas in PF controls it increased $(P<0.01$; Figure $5 \mathrm{C})$. Relative to baseline, total MPO of LPS-AvZn cows was decreased (10\%; $P$ $=0.02)$ at $24 \mathrm{~h}$ postbolus, whereas in LPS-CON cows it remained decreased (11\%) from 24 to $48 \mathrm{~h}$ postbolus $(P \leq 0.02)$. Total MPO in PF treatments increased (11\%) relative to baseline from 24 to $48 \mathrm{~h}$ postbolus $(P \leq 0.03)$. Throughout P2, LPS-administered cows had increased (18\%) MPO exocytosis relative to PF controls $(P<0.01$; Figure 5D). Relative to baseline, the percentage of MPO released after in vitro stimulation increased (41\%) in all treatments at $12 \mathrm{~h}$ postbolus $(P<0.01$; Figure 5D). Myeloperoxidase exocytosis was or tended to be increased throughout P2 in LPS-CON and LPS-AvZn treatments relative to baseline (37 and $22 \%$, respectively; $P<0.01$ and $P \leq 0.09$; Figure $5 \mathrm{D}$ ).

\section{DISCUSSION}

Maintenance of epithelial barrier function is crucial for preventing noxious substances and pathogen infiltration. When the intestinal barrier is compromised, antigens can infiltrate into portal and systemic circulation and initiate a cascade of events culminating in immunoactivation and inflammation. In dairy cows, there are myriad possible routes for pathogen entry, including the mammary gland, uterus, lungs, and gastrointestinal tract (Bradford et al., 2015). Although insult etiology may differ, animal welfare and economic profitability are almost always compromised by epithelial hyperper- 

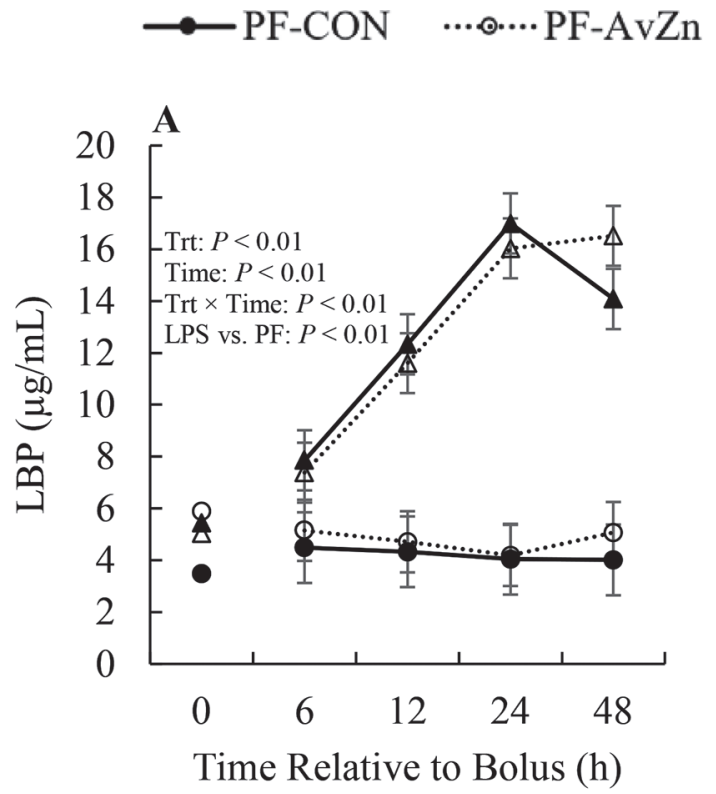
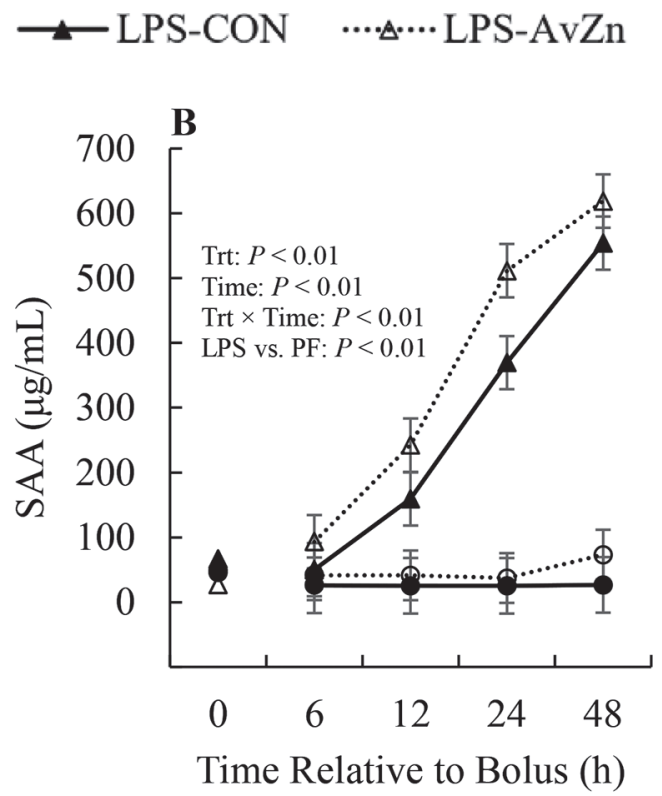

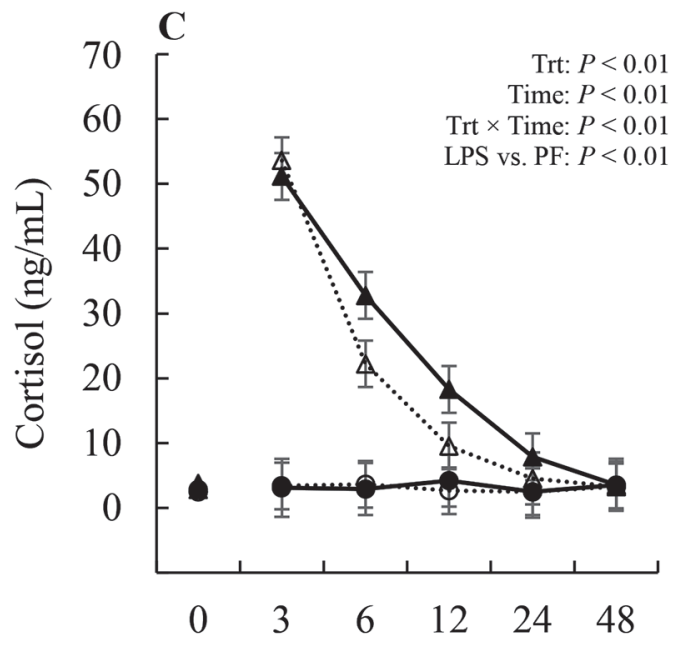

Time Relative to Bolus (h)

Figure 4. Effects of an LPS bolus or pair-feeding in dairy cows fed a control diet or a diet supplemented with a Zn AA complex on circulating (A) LPS-binding protein (LBP), (B) serum amyloid A (SAA), and (C) cortisol. Cows were randomly assigned to 1 of 2 dietary treatments: (1) control $\left(\mathrm{CON} ; 64 \mathrm{mg} / \mathrm{kg}\right.$ supplemental $\mathrm{Zn}$ from $\mathrm{ZnSO}_{4}$ ) or (2) replacement of $40 \mathrm{mg} / \mathrm{kg} \mathrm{ZnSO}$ with Zn AA complex (AvZn; Availa-Zn, Zinpro Corporation, Eden Prairie, MN). At the initiation of period 2 (P2), which lasted 48 h, animals either experienced a 12-h LPS euglycemic clamp as previously described (Kvidera et al., 2016, 2017a; Horst et al., 2018) or were pair-fed (PF) to their respective dietary counterparts for the entire $48 \mathrm{~h}$ to eliminate the confounding effects of dissimilar nutrient intake. Dietary and challenged combinations resulted in 4 treatments: (1) PF control diet (PF-CON; $5 \mathrm{~mL}$ of sterile saline with CON diet; $\mathrm{n}=5$ ), (2) PF Availa-Zn diet (PF-AvZn; $5 \mathrm{~mL}$ of sterile saline with AvZn diet; $\mathrm{n}=5$ ), (3) LPS euglycemic clamp control diet (LPS-CON; $0.375 \mu \mathrm{g}$ of LPS/kg of BW with CON diet; $\mathrm{n}=5$ ), and (4) LPS euglycemic clamp Availa-Zn diet (LPS-AvZn; $0.375 \mu \mathrm{g}$ of LPS $/ \mathrm{kg}$ of BW with AvZn diet; $\mathrm{n}=5$ ). Time 0 represents an average of measurements obtained during the baseline and used as a covariate for P2 and period 3 analysis. Fixed effects of treatment (Trt), time, and treatment $\times$ time were assessed as a completely randomized design using PROC MIXED of SAS (SAS Institute Inc., Cary, NC). Data are represented as LSM \pm SEM and considered significant if $P<0.05$ and a tendency if $0.05<P<0.10$. When $<0.10$, the $P$-value for the fixed effects and the preplanned contrasts are listed on the figure.

meability, due in large part to high energetic demands of activated leukocytes (Kvidera et al., 2017a,b). Successful immunoactivation relies on effective leukocyte communication, extravasation, cellular function, elimination of cell debris and harmful byproducts, and return to homeostasis (Kennedy, 2010). Identifying mitigation strategies aimed at improving barrier integrity (thus reducing pathogen entry) and immunocompetence have the potential to improve productivity over a range of physiological stressors. Zinc is involved in more than 
300 enzymes and plays a pivotal role in multiple systems (Prasad, 2012; Kambe et al., 2015). Furthermore, Zn improves epithelial integrity characteristics (mammary and intestinal; Sanz Fernandez et al., 2014; Weng et al., 2018) and immune function (cell adherence, clearance of E. coli, cytokine production; Kidd et al., 1994a; Finamore et al., 2008). Therefore, we hypothesized that supplemental complexed Zn would modify the inflammatory response to an intravenous LPS challenge and in turn alter the leukocyte energetic requirement.

Successful immunoactivation was induced herein as indicated by mild hyperthermia, increased circulating inflammatory biomarkers, altered leukocyte dynamics, and reduced productivity. Cows administered LPS experienced a mild and transient hyperthermia, and the extent and pattern agree with previous reports (Waldron et al., 2003; Moyes et al., 2014b; Horst et al., 2018). Interestingly, relative to LPS-CON cows, feeding complexed Zn reduced the febrile response to LPS. Both an increased (Roberts et al., 2002; Sanz Fernandez et al., 2014) and decreased (Chirase et al., 1991; Pearce et al., 2015; Abuajamieh et al., 2016) Tr response has been observed with complexed Zn following immunoactivation, and the variability is presumably cytokine driven. Circulating cytokines (e.g., tumor necrosis factor- $\alpha$ or IL-1 $\beta$ ) have pyrogenic properties and are altered by Zn in pigs (Klosterhalfen et al., 1996; Paulk et al., 2014; Mayorga et al., 2018), humans (Bao et al., 2010), chickens (Jarosz et al., 2017a), and cattle (Batistel et al., 2016). Although not always consistent (Driessen et al., 1994; Klosterhalfen et al., 1996; Batistel et al., 2016), Zn supplementation decreases circulating cytokines during inflammation via Zn-finger protein inhibition of the nuclear factor kappa light-chain enhancer of activated B cells pathway (Prasad, 2008; Foster and Samman, 2012; Jarosz et al., 2017b). Therefore, inconsistencies in the febrile response may be explained by the transient and variable pattern of circulating cytokines, the type of inflammatory insult, or stage of infection.

In response to immunogenic stimuli and cytokines, circulating APP (i.e., LBP and SAA) concentrations are markedly increased (Waldron et al., 2003; Kvidera et al., 2017a; Horst et al., 2018), which corroborates our results. During infection, circulating $\mathrm{Zn}$ is rapidly redistributed into cells and tissues (particularly the liver), where it alters APP production (Liuzzi et al., 2005; Liu et al., 2014). In the present study, feeding complexed Zn increased circulating SAA post-LPS infusion. Similarly, feeding complexed Zn increased APP production in heat-stressed calves and pigs (Pearce et al., 2015; Abuajamieh et al., 2016), chickens (Jarosz et al., 2019), and transitioning dairy cows (Batistel et al., 2016). Interestingly, Liu et al. (2014) demonstrated that Zn deficiency enhances APP production via activating the 
JAK-STAT3 pathway in a murine model. Regardless of the aforementioned inconsistencies, it is clear that $\mathrm{Zn}$ can influence the APP response.

Cytokines and APP produced in response to LPS direct cell traffic, activate circulating immune cells, and facilitate "killing" capacity, which markedly alters temporal leukocyte patterns. In the current study, leukopenia occurred immediately following LPS infusion, likely due to immune cell infiltration (into presumed infection sites) or increased leukocyte appearance in the marginated pool (Hoedemaker et al., 1992; Lang et al., 1992). After approximately $12 \mathrm{~h}$, leukocytosis
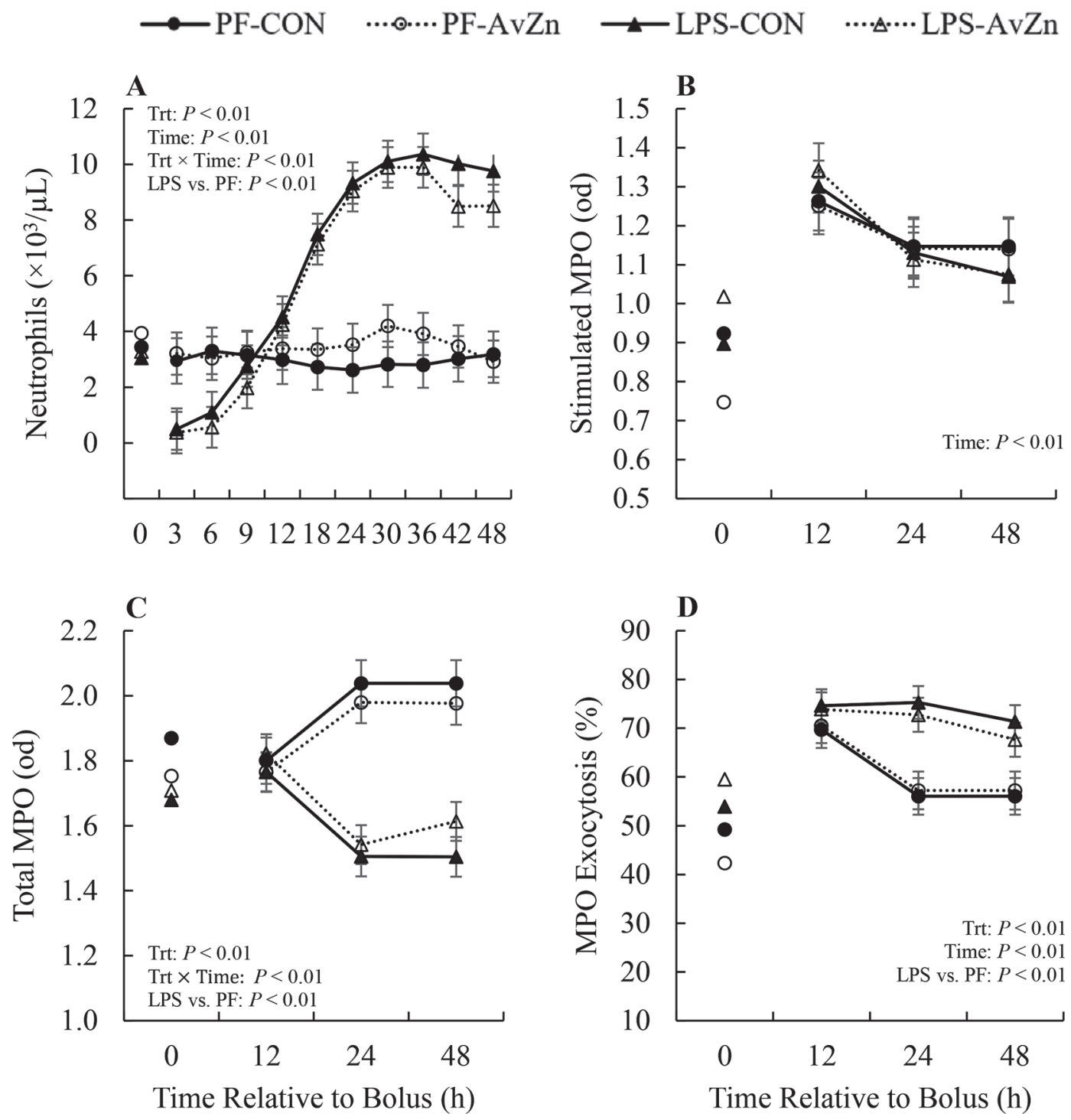

Figure 5. Effects of an LPS bolus or pair-feeding in dairy cows fed a control diet or a diet supplemented with a Zn AA complex on (A) circulating neutrophils, (B) neutrophil-stimulated myeloperoxidase (MPO) release, where od = optical density, (C) total MPO release, and (D) MPO exocytosis. Cows were randomly assigned to 1 of 2 dietary treatments: (1) control $\left(\mathrm{CON} ; 64 \mathrm{mg} / \mathrm{kg}\right.$ supplemental $\mathrm{Zn}$ from $\left.\mathrm{ZnSO}{ }_{4}\right)$ or $(2)$ replacement of $40 \mathrm{mg} / \mathrm{kg} \mathrm{ZnSO}$ with Zn AA complex (AvZn; Availa-Zn, Zinpro Corporation, Eden Prairie, MN). At the initiation of period 2 (P2), which lasted 48 h, animals either experienced a 12-h LPS euglycemic clamp as previously described (Kvidera et al., 2016, 2017a; Horst et al., 2018) or were pair-fed (PF) to their respective dietary counterparts for the entire $48 \mathrm{~h}$ to eliminate the confounding effects of dissimilar nutrient intake. Dietary and challenged combinations resulted in 4 treatments: (1) PF control diet (PF-CON; 5 mL of sterile saline with CON diet; $\mathrm{n}=5$ ), (2) PF Availa-Zn diet (PF-AvZn; $5 \mathrm{~mL}$ of sterile saline with AvZn diet; $\mathrm{n}=5$ ), (3) LPS euglycemic clamp control diet (LPS-CON; $0.375 \mu \mathrm{g}$ of LPS $/ \mathrm{kg}$ of BW with CON diet; $\mathrm{n}=5$ ), and (4) LPS euglycemic clamp Availa-Zn diet (LPS-AvZn; $0.375 \mu \mathrm{g}$ of LPS/kg of BW with AvZn diet; $\mathrm{n}=5$ ). Time 0 represents an average of measurements obtained during the baseline and used as a covariate for P2 and period 3 analysis. Fixed effects of treatment (Trt), time, and treatment $\times$ time were assessed as a completely randomized design using PROC MIXED of SAS (SAS Institute Inc., Cary, NC). Data are represented as LSM \pm SEM and considered significant if $P \leq 0.05$ and a tendency if $0.05<P$ $\leq 0.10$. When $<0.10$, the $P$-value for the fixed effects and the preplanned contrasts are listed on the figure. 
developed and was most pronounced in the neutrophil population. Neutrophilia may be due to increased neutrophil production, demargination from pulmonary circulation, or decreased endothelial adherence (Jagels and Hugli, 1994; Opdenakker et al., 1998). These fluctuating temporal patterns are consistent with LPS infusion in lactating cows (Bannerman et al., 2008; Horst et al., 2018).

Depending on the severity of infection, populations of immature or banded neutrophils are increased during neutrophilia, and the immature population's function is not fully operational (Van Eeden et al., 1995; Paape et al., 2003). Reduced ROS production, increased rates of apoptosis, and reduced adhesion molecule expression (Mehrzad et al., 2001; Yagi et al., 2002) have been observed in circulating neutrophils isolated from LPSinfused cows. However, improved function of bovine PMN has also been reported following LPS infusion or incubation (Sohn et al., 2007; Moyes et al., 2014a,b; Moraes et al., 2017). We detected no differences in respiratory burst or release of MPO in LPS-infused cows relative to their PF counterparts. Lipopolysaccharide administration decreased total MPO content and increased MPO exocytosis. Although LPS depleted MPO stores, it did not appear to affect the neutrophils' capacity to release MPO, suggesting an improved efficiency of neutrophils isolated from LPS-administered cows. Improved PMN activity in LPS cows may be explained by the maintenance of euglycemia following LPS administration. Infusing LPS markedly alters metabolic status (i.e., hypoglycemia, hyperinsulinemia, hypertriglyceridemia, hypergluconemia), and this metabolic milieu may contribute to immunosuppression (Moyes et al., 2010); thus, maintenance of euglycemia may have masked LPS-induced hypoglycemia effects on neutrophil function. No differences were observed due to $\mathrm{Zn}$ source on the temporal pattern of circulating leukocytes, which agrees with previous studies (Kidd et al., 1994b). Moreover, Zn source did not alter neutrophil oxidative burst or MPO production. The effect of dietary $\mathrm{Zn}$ on cellular and humoral immunity is extremely and unexplainably variable across species (Kidd et al., 1994a,b; Kincaid et al., 1997; Nemec et al., 2012; Dietz et al., 2017; Kloubert et al., 2018). The aforementioned inconsistencies may be due to cell type measured, methods for assessing neutrophil function, or pre-existing Zn status.

Although the mechanisms underlying immunosuppression in immature leukocyte populations remain unclear, one hypothesis is an increase in immunosuppressive glucocorticoids, such as cortisol (Burton et al., 1995, 2005). Surprisingly, despite hypercortisolemia, we observed no effect or even improved PMN function (i.e., increased MPO exocytosis) following LPS infusion. Additionally, LPS-AvZn cows had decreased circulating cortisol relative to LPS-CON cows, which agrees with previous studies (Dang et al., 2013; Lippolis et al., 2017). Explanations for why AvZn-induced decreased cortisol did not affect PMN function are not clear; however, cortisol concentrations had almost returned to baseline values before PMN isolation, and it is not clear how long neutrophils need to be exposed to corticosteroids before becoming less functional. Additionally, leukocytes can develop steroid intolerance to immunosuppressive glucocorticoids (Briggs et al., 1983; Snavely et al., 1985). Even though the decrease in cortisol did not coincide with changes in neutrophil activity, it may suggest that the LPS insult was less severe with complexed Zn supplementation, and this agrees with the reduced febrile response. The biological significance of Zn-mediated decreased cortisol warrants further investigation because it has relevance to multiple on-farm situations (e.g., the transition period, heat stress, and transport stress).

Lipopolysaccharide intravenous infusion reduces the integrity of mammary (Wellnitz et al., 2016) and intestinal epithelial barriers (Klunker et al., 2013). In the current study, we observed increased SCC in LPSinfused cows relative to $\mathrm{PF}$ controls during $\mathrm{P} 2$, which agrees with previous work (Shuster et al., 1991; Kvidera et al., 2017a). Additionally, plasma lactose (a biomarker of reduced mammary barrier function; Shennan and Peaker, 2000) concentrations increased post-LPS infusion. Interestingly, during P3, SCC of LPS-AvZn cows was decreased relative to their LPS-CON counterparts. Reduced milk SCC has been observed repeatedly with dietary Zn supplementation (Kellogg et al., 2004; Machado et al., 2013; Nayeri et al., 2014), and Weng et al. (2018) recently observed reduced circulating lactose with Zn supplementation in heat-stressed cows. Zinc is required for normal epithelial barrier function and has been shown to improve integrity characteristics of mammary (Weng et al., 2018), lung (Bao and Knoell, 2006), and intestinal epithelial barriers (Sanz Fernandez et al., 2014; Pearce et al., 2015; Abuajamieh et al., 2016). Therefore, $\mathrm{Zn}$ appears to be a promising mitigation strategy for strengthening the integrity of multiple epithelial barriers, and it is of interest to evaluate whether dietary Zn can improve uterine epithelial integrity.

In addition to markedly initiating an inflammatory response and compromising mammary epithelial integrity, several well-characterized metabolic adjustments (hyperglycemia or hypoglycemia, depending on the stage of infection; hyperglucagonemia and hyperinsulinemia; increased markers of proteolysis; and hypertriglyceridemia) occur post-LPS infusion (Lohuis et al., 1988; Lanza-Jacoby et al., 1998; McGuinness, 2005). These changes, along with reduced insulin sensitiv- 
ity in skeletal muscle and adipose tissue coupled with decreased milk synthesis, reflect coordinated strategies that facilitate glucose "sparing" for immune cells. Most leukocytes become obligate glucose utilizers when activated (Palsson-McDermott and O'Neill, 2013) and require copious amounts of glucose. In the present study, the glucose requirement of the immune system was approximately $0.96 \mathrm{~g} / \mathrm{kg}$ of $\mathrm{BW}^{0.75}$ per hour, which is remarkably comparable with our previous studies in monogastrics and ruminants (Kvidera et al., 2016, 2017a,b; Horst et al., 2018). However, despite numerous indications of an altered inflammatory response (i.e., reduced pyrexia, increased SAA, and reduced cortisol), dietary Zn source did not appear to affect overall glucose use by the immune system. However, a clear limitation to our model is the inability to account for the liver's contribution (i.e., glycogenolysis and gluconeogenesis) to the circulating glucose pool. Both glycogenolytic and gluconeogenic rates increase following LPS administration (Spitzer et al., 1985; McGuinness, 1994; Waldron et al., 2003), and we are unable to quantify the liver's glucose output, a scenario that causes the total glucose deficit to be underestimated. Additionally, we observed increased circulating glucagon in LPS-infused cows, and glucagon is a potent stimulator of both glycogenolysis and gluconeogenesis (Faulkner and Pollock, 1990). Interestingly, feeding complexed $\mathrm{Zn}$ decreased the acute hyperglycemic response to LPS and blunted the post-LPS glucagon surge. Both of the aforementioned changes may suggest that there was less of a glucose demand in complexed Zn-fed cows, and this is corroborated by altered inflammation parameters. Further investigation into how dietary Zn modifies the immune system and immunometabolism is needed.

Many of the well-characterized glucose-sparing mechanisms mentioned previously occurred post-LPS administration in our study. Marked hyperinsulinemia developed immediately postbolus and was sustained throughout the sampling period. Increased insulin presumably supports insulin-mediated glucose uptake and function of activated leukocytes (Calder et al., 2007). Although not significant, we observed a numerical decrease in circulating insulin in LPS-AvZn cows relative to their LPS-CON counterparts during the first $12 \mathrm{~h}$ postbolus. Zinc plays a pivotal role in processing, storage, secretion, and action of insulin (Myers et al., 2012); furthermore, $\mathrm{Zn}$ has been shown to attenuate glucose-stimulated insulin secretion (Slepchenko et al., 2013) via inhibiting tyrosine phosphatases (Haase and Maret, 2005). Literature demonstrating a beneficial effect of organic versus inorganic forms of $\mathrm{Zn}$ on circulating insulin is limited and warrants further investigation. Regardless, the combined effects of complexed Zn on post-LPS circulating insulin and glucagon suggest a coordinated response reflective of a reduced glucose requirement during the acute stage of infection.

Nonesterified fatty acids decreased following LPS administration and then gradually increased with time. Interestingly, circulating NEFA from LPS-AvZn cows decreased relative to LPS-CON cows. Two possible mechanisms for blunted lipolysis may be (1) increased insulin antilipolytic sensitivity or (2) antilipolytic effects of increased circulating lactate. Although Zn has been shown to alter insulin sensitivity (Slepchenko et al., 2013), the results should be interpreted with caution because pre-existing Zn status (i.e., deficiency) may influence this response. Amplified leukocyte proliferation and activity increases lactate efflux, and this can cause infection-induced hyperlactatemia (Haji-Michael et al., 1999). Although not observed in the neutrophil parameters we measured, if $\mathrm{Zn}$ increased cellular activity of another white blood cell type, hyperlactatemia may have developed and altered lipolysis. Regardless of the mechanism, the biological significance of reduced lipolysis remains unclear and warrants further investigation. Despite observing an altered NEFA pattern, circulating BHB concentrations did not differ in LPSCON and LPS-AvZn cows. Circulating BHB remained decreased during P2, possibly due to increased utilization by peripheral tissues (Zarrin et al., 2014). However, decreased BHB production from the liver (Takeyama et al., 1990; Gitomer et al., 1995) and rumen epithelium may also contribute to the LPS-induced hypoketonemia. Further investigation into the LPS-induced hypoketonemia is warranted, especially considering its relevance to the transition cow's bioenergetics. Skeletal muscle mobilization, as measured by circulating BUN, increased throughout P2. Proteolysis provides substrate for gluconeogenesis and AA for APP synthesis. However, BUN can be difficult to interpret in ruminant models because muscle proteolysis is not the sole source of urea. Regardless, these metabolic adjustments are consistent with previous literature (Waldron et al., 2003; Graugnard et al., 2013; Zarrin et al., 2014) and discussed further in our recent publications (Kvidera et al., 2016, 2017a,b; Horst et al., 2018).

Hypocalcemia develops in infection models across a range of species, including calves (Tennant et al., 1973; Elsasser et al., 1996), dogs (Holowaychuk et al., 2012), horses (Toribio et al., 2005), pigs (Carlstedt et al., 2000), sheep (Naylor and Kronfeld, 1986), and cows (Griel et al., 1975; Waldron et al., 2003; Kvidera et al., 2017a). The biological significance of infection-induced hypocalcemia is not fully understood, but past literature has demonstrated a relationship between $\mathrm{Ca}$ and LPS detoxification (Skarnes and Chedid, 1964); this was recently reviewed by Eckel and Ametaj (2016). Interestingly, complexed Zn supplementation attenuated 
LPS-induced hypocalcemia at $12 \mathrm{~h}$ postbolus (Figure $3 \mathrm{E})$. This may suggest that the LPS load was dampened in LPS-AvZn cows at $12 \mathrm{~h}$ postbolus compared with LPS-CON, perhaps due to improved integrity of mammary and intestinal epithelial barriers or improved LPS detoxification methods. A reduced LPS load is fitting with the other observations described previously (i.e., reduced fever, increased SAA, reduced cortisol, reduced SCC, decreased insulin and glucagon). The biological significance of ameliorated hypocalcemia due to $\mathrm{Zn}$ source warrants further investigation because it has practical relevance to periparturient metabolic disorders.

Determining differences in production outcomes was not the primary objective, as the experiment was knowingly underpowered to detect treatment differences in such variable measurements. Nonetheless, analyzing and presenting production variables allows for the primary aims (i.e., immune response, glucose deficit, and metabolism) to be put into context. Administrating LPS markedly decreased DMI, and by experimental design the PF controls mirrored this pattern and magnitude of reduced DMI during P2. The total glucose deficit of PF treatments was accounted for exclusively by the decrease in milk yield because the cows did not become hypoglycemic, whereas the glucose deficit from the LPS treatments included the decrease in milk yield in addition to infused glucose. Although cows remained on the same nutritional plane, the milk glucose deficit from LPS treatments was increased $75 \%$ relative to the $\mathrm{PF}$ controls. In agreement with our previous studies (Kvidera et al., 2017a; Horst et al., 2018), maintaining euglycemia did not rescue milk yield in LPS-administered cows, confirming that hypoglycemia is not responsible for reduced milk synthesis during infection. Reduced milk production represents an important glucose-sparing mechanism during infection and may occur either directly via LPS binding to mammary epithelial Toll-like receptor 4 or indirectly by increased proinflammatory cytokines (Verheijden et al., 1983; IbeaghaAwemu et al., 2008). During P3, cows in all treatments were allowed to consume feed ad libitum; however, DMI and milk yield remained decreased in cows previously administered LPS relative to PF controls, demonstrating the prolonged consequences of inflammation. Interestingly, although overall DMI and milk yield were not affected by diet during P2 and P3, LPS-AvZn cows had an increased rate (49\%) of recovery in milk yield from d 1 to 3 relative to their LPS-CON counterparts. Although not observed as frequently for DMI (Osorio et al., 2016), complexed Zn has been shown to improve milk yield in lactating dairy cows (Kellogg et al., 2004; Nayeri et al., 2014; Osorio et al., 2016). Reasons for not detecting more $\mathrm{Zn}$ differences in production parameters may be explained by small sample size, severity of the immune insult, and length of study.

\section{CONCLUSIONS}

Our results indicate that immunoactivation requires copious amounts of glucose, but Zn source did not appear to affect the immune system's fuel consumption. However, replacing a portion of $\mathrm{Zn}$ sulfate with $\mathrm{Zn}$ AA complex improved some inflammatory, metabolic, and production responses to LPS. The reduced hyperglycemic phase coupled with decreased circulating glucagon and insulin concentrations demonstrate a dampened metabolic requirement following immunoactivation with complexed Zn supplementation. Further, multiple changes in the inflammatory response coincided with altered energetics, including reduced fever, circulating cortisol, and SCC; increased SAA concentrations; and attenuated hypocalcemia. Our results demonstrate wellcoordinated alterations in metabolic and inflammatory parameters with complexed Zn supplementation during immunoactivation.

\section{ACKNOWLEDGMENTS}

This project was supported in part by Zinpro Corporation (Eden Prairie, MN), the Agricultural and Food Research Initiative Competitive Grant no. 2017-05931 from the USDA National Institute of Food and Agriculture (Washington, DC), and the Norman Jacobson Endowed Professorship.

\section{REFERENCES}

Abuajamieh, M., S. K. Kvidera, E. A. Horst, E. J. Mayorga, J. T. Seibert, J. S. Johnson, J. W. Ross, M. A. Al-Qaisi, P. J. Gorden, J. DeFrain, R. P. Rhoads, and L. H. Baumgard. 2016. The effects of zinc amino acid complex on biomarkers of gut integrity and metabolism in heat-stressed steers. J. Dairy Sci. 99(E-Suppl. 1):1175. (Abstr.)

Alam, A. N., S. A. Sarker, and M. A. Wahed. 1994. Enteric protein loss and intestinal permeability changes in children during acute shigellosis and after recovery: Effect of zinc supplementation. Gut 35:1707-1711.

AOAC International. 1995. AOAC official method 972.16. Fat, lactose protein, and solids in milk. Mid infrared spectroscopic method. Pages 23-26 in Official Methods of Analysis. 16th ed. Vol. 2. AOAC International, Arlington, VA.

Bannerman, D. D., A. C. W. Kauf, M. J. Paape, H. R. Springer, and J. P. Goff. 2008. Comparison of Holstein and Jersey innate immune responses to Escherichia coli intramammary infection. J. Dairy Sci. 91:2225-2235.

Bao, B., A. S. Prasad, F. W. J. Beck, J. T. Fitzgerald, D. Snell, G. W. Bao, T. Singh, and L. J. Cardozo. 2010. Zinc decreases C-reactive protein, lipid peroxidation, and inflammatory cytokine in elderly subjects: A potential implication of zinc as an atheroprotective agent. Am. J. Clin. Nutr. 91:1634-1641.

Bao, S., and D. L. Knoell. 2006. Zinc modulates cytokine-induced lung epithelial cell barrier permeability. Am. J. Physiol. Lung Cell. Mol. Physiol. 291:L1132-L1141. 
Batistel, F., J. S. Osorio, A. Ferrari, E. Trevisi, M. T. Socha, and J. J. Loor. 2016. Immunometabolic status during the peripartum period is enhanced with supplemental $\mathrm{Zn}, \mathrm{Mn}$, and $\mathrm{Cu}$ from amino acid complexes and Co from Co glucoheptonate. PLoS One 11:e0155804

Baumgard, L. H., R. J. Collier, and D. E. Bauman. 2017. A 100-year review: Regulation of nutrient partitioning to support lactation. J. Dairy Sci. 100:10353-10366.

Baumgard, L. H., J. B. Wheelock, S. R. Sanders, C. E. Moore, H. B. Green, M. R. Waldron, and R. P. Rhoads. 2011. Postabsorptive carbohydrate adaptations to heat stress and monensin supplementation in lactating Holstein cows. J. Dairy Sci. 94:5620-5633.

Bertoni, G., E. Trevisi, X. Han, and M. Bionaz. 2008. Effects of inflammatory conditions on liver activity in puerperium period and consequences for performance in dairy cows. J. Dairy Sci. 91:33003310 .

Bradford, B. J., K. Yuan, J. K. Farney, L. K. Mamedova, and A. J. Carpenter. 2015. Invited review: Inflammation during the transition to lactation: New adventures with an old flame. J. Dairy Sci. 98:6631-6650.

Briggs, M. M., J. M. Stadel, R. Iyengar, and R. J. Lefkowitz. 1983. Functional modification of the guanine nucleotide regulatory protein after desensitization of turkey erythrocytes by catecholamines. Arch. Biochem. Biophys. 224:142-151.

Burton, J. L., M. E. Kehrli, S. Kapil, and R. L. Horst. 1995. Regulation of L-selectin and CD18 on bovine neutrophils by glucocorticoids: Effects of cortisol and dexamethasone. J. Leukoc. Biol. $57: 317-325$.

Burton, J. L., S. A. Madsen, L. C. Chang, P. S. D. Weber, K. R. Buckham, R. V. Dorp, M. C. Hickey, and E. Bernadette. 2005. Gene expression signatures in neutrophils exposed to glucocorticoids: A new paradigm to help explain "neutrophil dysfunction" in parturient dairy cows. Vet. Immunol. Immunopathol. 105:197-219.

Calder, P. C., G. Dimitriadis, and P. Newsholme. 2007. Glucose metabolism in lymphoid and inflammatory cells and tissues. Curr. Opin. Clin. Nutr. Metab. Care 10:531-540.

Carlstedt, F., M. Eriksson, R. Kiiski, A. Larsson, and L. Lind. 2000. Hypocalcemia during porcine endotoxemic shock: Effects of calcium administration. Crit. Care Med. 28:2909-2914.

Chirase, N. K., D. P. Hutcheson, and G. B. Thompson. 1991. Feed intake, rectal temperature, and serum mineral concentrations of feedlot cattle fed zinc oxide or zinc methionine and challenged with infectious bovine rhinotracheitis virus. J. Anim. Sci. 69:4137-4145.

Dang, A. K., M. Jamwal, M. Kaur, S. P. Kimonthi, S. Pal, K. De, M. M. Pathan, D. J. Swain, S. K. Mohapatra, S. Kapila, R. Kapila, H. Kaur, A. K. Mohanty, and B. S. Prakash. 2013. Effect of micronutrient supplementation around calving on the plasma cortisol levels of Murrah buffaloes and Sahiwal and Karan Fries cows. Trop. Anim. Health Prod. 45:1047-1050.

Dietz, A. M., W. P. Weiss, M. J. Faulkner, and J. S. Hogan. 2017. Short communication: Effects of supplementing diets of Holsteins with copper, zinc, and manganese on blood neutrophil function. J. Dairy Sci. 100:2201-2206.

Driessen, C., K. Hirv, L. Rink, and H. Kirchner. 1994. Induction of cytokines by zinc ions in human peripheral blood mononuclear cells and separated monocytes. Lymphokine Cytokine Res. 13:15-20.

Eckel, E. F., and B. N. Ametaj. 2016. Invited review: Role of bacterial endotoxins in the etiopathogenesis of periparturient diseases of transition dairy cows. J. Dairy Sci. 99:5967-5990.

Elsasser, T. H., M. Richards, R. Collier, and G. F. Hartnell. 1996. Physiological responses to repeated endotoxin challenge are selectively affected by recombinant bovine somatotropin administration to calves. Domest. Anim. Endocrinol. 13:91-103.

Faulkner, A., and H. T. Pollock. 1990. Effects of glucagon and $\alpha$ - and $\beta$-agonists on glycogenolysis and gluconeogenesis in isolated ovine hepatocytes. Biochim. Biophys. Acta 1052:229-234.

Finamore, A., M. Massimi, L. Conti Devirgiliis, and E. Mengheri. 2008 Zinc deficiency induces membrane barrier damage and increases neutrophil transmigration in Caco-2 cells. J. Nutr. 138:1664-1670.
Foster, M., and S. Samman. 2012. Zinc and regulation of inflammatory cytokines: Implications for cardiometabolic disease. Nutrients 4:676-694.

Giri, S. N., P. Emau, J. S. Cullor, G. H. Stabenfeldt, M. L. Bruss, R. H. Bondurant, and B. I. Osburn. 1990. Effects of endotoxin infusion on circulating levels of eicosanoids, progesterone, cortisol, glucose and lactic acid, and abortion in pregnant cows. Vet. Microbiol. 21:211-231.

Gitomer, W. L., B. C. Miller, and G. L. Cottam. 1995. In vivo effects of lipopolysaccharide on hepatic free- $\mathrm{NAD}(\mathrm{P})(+)$-linked redox states and cytosolic phosphorylation potential in 48-hour-fasted rats. Metabolism 44:1170-1174.

Graugnard, D. E., K. M. Moyes, E. Trevisi, M. J. Khan, D. Keisler, J. K. Drackley, G. Bertoni, and J. J. Loor. 2013. Liver lipid content and inflammometabolic indices in peripartal dairy cows are altered in response to prepartal energy intake and postpartal intramammary inflammatory challenge. J. Dairy Sci. 96:918-935

Griel, L. C., A. Zarkower, and R. J. Eberhart. 1975. Clinical and clinico-pathological effects of Escherichia coli endotoxin in mature cattle. Can. J. Comp. Med. 39:1-6.

Haase, H., and W. Maret. 2005. Protein tyrosine phosphatases as targets of the combined insulinomimetic effects of zinc and oxidants. Biometals 18:333-338.

Haase, H., and L. Rink. 2014. Zinc signals and immune function. Biofactors 40:27-40.

Haji-Michael, P. G., L. Ladriére, A. Sener, J. Vincent, and W. J. Malaisse. 1999. Leukocyte glycolysis and lactate output in animal sepsis and ex vivo human blood. Metabolism 48:779-785.

Hoedemaker, M., L. A. Lund, and W. C. Wagner. 1992. Function of neutrophils and chemoattractant properties of fetal placental tissue during the last month of pregnancy in cows. Am. J. Vet. Res. $53: 1524-1529$

Holowaychuk, M. K., A. J. Birkenheuer, J. Li, H. Marr, A. Boll, and S. K. Nordone. 2012. Hypocalcemia and hypovitaminosis D in dogs with induced endotoxemia. J. Vet. Intern. Med. 26:244-251.

Horst, E. A., S. K. Kvidera, E. J. Mayorga, C. S. Shouse, M. Al-Qaisi, M. J. Dickson, J. Ydstie, H. A. Ramirez Ramirez, A. F. Keating, D. J. Dickson, K. E. Griswold, and L. H. Baumgard. 2018. Effect of chromium on bioenergetics and leukocyte dynamics following immunoactivation in lactating Holstein cows. J. Dairy Sci 101:5515-5530.

Ibeagha-Awemu, E. M., J. W. Lee, A. E. Ibeagha, D. D. Bannerman, M. J. Paape, and X. Zhao. 2008. Bacterial lipopolysaccharide induced increased expression of toll-like receptor (TLR) 4 and downstream TLR signaling molecules in bovine mammary epithelial cells. Vet. Res. 39:11.

Jagels, M. A., and T. E. Hugli. 1994. Mechanisms and mediators of neutrophilic leukocytosis. Immunopharmacology 28:1-18.

Jarosz, Ł., A. Marek, Z. Gradzki, M. Kwiecień, and M. Kalinowski 2017a. The effect of feed supplementation with zinc chelate and zinc sulphate on selected humoral and cell-mediated immune parameters and cytokine concentration in broiler chickens. Res. Vet. Sci. 112:59-65.

Jarosz, Ł.. A. Marek, Z. Gradzki, E. Laskowska, and M. Kwiecień 2019. Effect of zinc sulfate and zinc glycine chelate on concentrations of acute phase proteins in chicken serum and liver tissue. Biol. Trace Elem. Res. 187:258-272.

Jarosz, M., M. Olbert, G. Wyszogrodzka, K. Mlyniec, and T. Librowski. 2017b. Antioxidant and anti-inflammatory effects of zinc. Zincdependent NF- $\kappa$ B signaling. Inflammopharmacology 25:11-24.

Johnson, R. W. 2012. Fueling the immune response: What's the cost? Pages 211-223 in Feed Efficiency in Swine. John Patience, ed. Wageningen Academic Publishers, Wageningen, the Netherlands.

Kambe, T., T. Tsuji, A. Hashimoto, and N. Itsumara. 2015. The physiological, biochemical, and molecular roles of zinc transporters in zinc homeostasis and metabolism. Physiol. Rev. 95:749-784.

Kellogg, D. W., D. J. Tomlinson, M. T. Socha, and A. B. Johnson. 2004. Effects of zinc methionine complex on milk production and somatic cell count of dairy cows: Twelve-trial summary. Prof. Anim. Sci. 20:295-301. 
Kennedy, M. A. 2010. A brief review of the basics of immunology: The innate and adaptive response. Vet. Clin. North Am. Small Anim. Pract. 40:369-379.

Khafipour, E., D. O. Krause, and J. C. Plaizier. 2009. A grain-based subacute ruminal acidosis challenge causes translocation of lipopolysaccharide and triggers inflammation. J. Dairy Sci. 92:10601070.

Kidd, M. T., M. A. Qureshi, P. R. Ferket, and L. N. Thomas. 1994a. Blood clearance of Escherichia coli and evaluation of mononuclearphagocytic system as influenced by supplemental dietary zinc methionine in young turkeys. Poult. Sci. 73:1381-1389.

Kidd, M. T., M. A. Qureshi, P. R. Ferket, and L. N. Thomas. 1994b. Dietary zinc-methionine enhances mononuclear-phagocytic function in young turkeys. Biol. Trace Elem. Res. 42:217-229.

Kimura, K., J. P. Goff, P. Canning, C. Wang, and J. A. Roth. 2014. Effect of recombinant bovine granulocyte colony-stimulating factor covalently bound to polyethylene glycol injection on neutrophil number and function in periparturient dairy cows. J. Dairy Sci. 97:4842-4851.

Kincaid, R. L., B. P. Chew, and J. D. Cronrath. 1997. Zinc oxide and amino acids as sources of dietary zinc for calves: Effects on uptake and immunity. J. Dairy Sci. 80:1381-1388.

Klosterhalfen, B., C. Töns, S. Hauptmann, L. Tietze, F. A. Offner, W. Küpper, and C. J. Kirkpatrick. 1996. Influence of heat shock protein 70 and metallothionein induction by zinc-bis-(DL-hydrogenaspartate) on the release of inflammatory mediators in a porcine model of recurrent endotoxemia. Biochem. Pharmacol. 52:12011210.

Kloubert, V., K. Blaabjerg, T. S. Dalgaard, H. D. Poulsen, L. Rink, and I. Wessels. 2018. Influence of zinc supplementation on immune parameters in weaned pigs. J. Trace Elem. Med. Biol. 49:231-240.

Klunker, L. R., S. Kahlert, P. Panther, A. K. Diesing, N. Reinhardt, B. Brosig, S. Kersten, S. Dänicke, H. J. Rothkötter, and J. W. Kluess. 2013. Deoxynivalenol and E. coli lipopolysaccharide alter epithelial proliferation and spatial distribution of apical junction proteins along the small intestinal axis. J. Anim. Sci. 91:276-285.

Koch, F., U. Thom, E. Albrecht, R. Weikard, W. Nolte, B. Kuhla, and C. Kuehn. 2019. Heat stress directly impairs gut integrity and recruits distinct immune cell populations into the bovine intestine. Proc. Natl. Acad. Sci. USA 116:10333-10338.

Kronfeld, D. S. 1982. Major metabolic determinants of milk volume, mammary efficiency, and spontaneous ketosis in dairy cows. J. Dairy Sci. 65:2204-2212.

Kvidera, S. K., E. A. Horst, M. Abuajamieh, E. J. Mayorga, M. V. Sanz Fernandez, and L. H. Baumgard. 2016. Technical note: A procedure to estimate glucose requirements of an activated immune system in steers. J. Anim. Sci. 94:4591-4599.

Kvidera, S. K., E. A. Horst, M. Abuajamieh, E. J. Mayorga, M. V. Sanz Fernandez, and L. H. Baumgard. 2017a. Glucose requirements of an activated immune system in lactating Holstein cows. J. Dairy Sci. 100:2360-2374.

Kvidera, S. K., E. A. Horst, E. J. Mayorga, M. V. Sanz-Fernandez, M. Abuajamieh, and L. H. Baumgard. 2017b. Estimating glucose requirements of an activated immune system in growing pigs. J. Anim. Sci. 95:5020-5029.

Kvidera, S. K., E. A. Horst, M. V. Sanz Fernandez, M. Abuajamieh, S. Ganesan, P. J. Gorden, H. B. Green, K. M. Schoenberg, W. E. Trout, A. F. Keating, and L. H. Baumgard. 2017c. Characterizing effects of feed restriction and glucagon-like peptide 2 administration on biomarkers of inflammation and intestinal morphology. J. Dairy Sci. 100:9402-9417.

Lang, C. H., G. J. Bagby, C. Dobrescu, A. Ottlakan, and J. J. Spitzer. 1992. Sepsis- and endotoxin-induced increase in organ glucose uptake in leukocyte-depleted rats. Am. J. Physiol. 263:R1324-R1332.

Lanza-Jacoby, S., H. Phetteplace, N. Sedkova, and G. Knee. 1998. Sequential alterations in tissue lipoprotein lipase, triglyceride secretion rates, and serum tumor necrosis factor alpha during Escherichia coli bacteremic sepsis in relation to the development of hypertriglyceridemia. Shock 9:46-51.

Lippolis, K. D., R. F. Cooke, L. G. T. Silva, K. M. Schubach, A. P. Brandao, R. S. Marques, C. K. Larson, J. R. Russell, S. A. Arispe,
T. DelCurto, and D. W. Bohnert. 2017. Effects of organic complexed or inorganic $\mathrm{Co}, \mathrm{Cu}, \mathrm{Mn}$, and $\mathrm{Zn}$ supplementation during a 45-day preconditioning period on productive and health responses of feeder cattle. Animal 11:1949-1956.

Liu, M. J., S. Bao, J. R. Napolitano, D. L. Burris, L. Yu, S. Tridandapani, and D. L. Knoell. 2014. Zinc regulates the acute phase response and serum amyloid A production in response to sepsis through JAK-STAT3 signaling. PLoS One 9:e94934.

Liuzzi, J. P., L. A. Lichten, S. Rivera, R. K. Blanchard, T. B. Aydemir, M. D. Knutson, T. Ganz, and R. J. Cousins. 2005. Interleukin-6 regulates the zinc transporter Zip 14 in liver and contributes to the hypozincemia of the acute-phase response. Proc. Natl. Acad. Sci. USA 102:6843-6848.

Lohuis, J. A., J. H. Verheijden, C. Burvenich, and A. S. van Miert. 1988. Pathophysiological effects of endotoxins in ruminants. 2. Metabolic aspects. Vet. Q. 10:117-125.

Machado, V. S., M. L. S. Bicalho, R. V. Pereira, L. S. Caixeta, W. A. Knauer, G. Oikonomou, R. O. Gilbert, and R. C. Bicalho. 2013. Effect of an injectable trace mineral supplement containing selenium, copper, zinc, and manganese on the health and production of lactating cows. Vet. J. 197:451-456.

Mayorga, E. J., S. K. Kvidera, E. A. Horst, M. A. Al-Qaisi, M. J. Dickson, J. T. Seibert, S. Lei, Z. J. Rambo, M. E. Wilson, and L. H. Baumgard. 2018. Effects of zinc amino acid complex on biomarkers of gut integrity and metabolism during and following heat stress or feed restriction in pigs. J. Anim. Sci. 96:4173-4185.

McGuinness, O. P. 1994. The impact of infection on gluconeogenesis in the conscious dog. Shock 2:336-343.

McGuinness, O. P. 2005. Defective glucose homeostasis during infection. Annu. Rev. Nutr. 25:9-35.

Mehrzad, J., H. Dosogne, E. Meyer, and C. Burvenich. 2001. Local and systemic effects of endotoxin mastitis on the chemiluminescence of milk and blood neutrophils in dairy cows. Vet. Res. 32:131-144.

Moraes, J. G. N., L. G. D. Mendonca, P. R. B. Silva, A. A. Scanavez, K. N. Galvão, M. A. Ballou, M. Worku, and R. C. Chebel. 2017. Effects of intrauterine infusion of Escherichia coli lipopolysaccharide on uterine mRNA gene expression and peripheral polymorphonuclear leukocytes in Jersey cows diagnosed with purulent vaginal discharge. J. Dairy Sci. 100:4784-4796.

Moyes, K. M., J. K. Drackley, D. E. Morin, and J. J. Loor. 2010. Greater expression of TLR2, TLR4, and IL6 due to negative energy balance is associated with lower expression of HLA-DRA and HLA-A in bovine blood neutrophils after intramammary mastitis challenge with Streptococcus uberis. Funct. Integr. Genomics 10:53-61

Moyes, K. M., D. E. Graugnard, M. J. Khan, M. Mukesh, and J. J. Loor. 2014a. Postpartal immunometabolic gene network expression and function in blood neutrophils are altered in response to prepartal energy intake and postpartal intramammary inflammatory challenge. J. Dairy Sci. 97:2165-2177.

Moyes, K. M., T. Larsen, P. Sørensen, and K. L. Ingvartsen. 2014b. Changes in various metabolic parameters in blood and milk during experimental Escherichia coli mastitis for primiparous Holstein dairy cows during early lactation. J. Anim. Sci. Biotechnol. 5:47.

Myers, S. A., A. Nield, and M. Myers. 2012. Zinc transporters, mechanisms of action and therapeutic utility: Implications for type 2 diabetes mellitus. J. Nutr. Metab. 2012:173712.

National Research Council. 2001. Nutrient Requirements of Dairy Cattle. 7th rev. ed. Natl. Acad. Press, Washington, DC.

Nayeri, A., N. C. Upah, E. Sucu, M. V. Sanz-Fernandez, J. M. DeFrain, P. J. Gorden, and L. H. Baumgard. 2014. Effect of the ratio of zinc amino acid complex to zinc sulfate on the performance of Holstein cows. J. Dairy Sci. 97:4392-4404.

Naylor, J. M., and D. S. Kronfeld. 1986. Relationships between metabolic changes and clinical signs in pregnant sheep given endotoxin. Can. J. Vet. Res. 50:402-409.

Nemec, L. M., J. D. Richards, C. A. Atwell, D. E. Diaz, G. I. Zanton, and T. F. Gressley. 2012. Immune responses in lactating Holstein cows supplemented with $\mathrm{Cu}, \mathrm{Mn}$, and $\mathrm{Zn}$ as sulfates or methionine hydroxyl analogue chelates. J. Dairy Sci. 95:4568-4577. 
Opdenakker, G., W. E. Fibbe, and J. Van Damme. 1998. The molecular basis of leukocytosis. Immunol. Today 19:182-189.

Osorio, J. S., E. Trevisi, C. Li, J. K. Drackley, M. Socha, and J. J. Loor. 2016. Supplementing Zn, Mn, and Cu from amino acid complexes and Co from cobalt glucoheptonate during the peripartal period benefits postpartal cow performance and blood neutrophil function. J. Dairy Sci. 99:1868-1883.

Paape, M. J., D. D. Bannerman, X. Zhao, and J. W. Lee. 2003. The bovine neutrophil: Structure and function in blood and milk. Vet. Res. 34:597-627.

Palsson-McDermott, E. M., and L. A. O'Neill. 2013. The Warburg effect then and now: From cancer to inflammatory diseases. BioEssays 35:965-973.

Paulk, C. B., D. D. Burnett, M. D. Tokach, J. L. Nelssen, S. S. Dritz, J. M. DeRouchey, R. D. Goodband, G. M. Hill, K. D. Hayden, and J. M. Gonzalez. 2014. Effect of added zinc in diets with ractopamine hydrochloride on growth performance, carcass characteristics, and ileal mucosal inflammation mRNA expression of finishing pigs. J. Anim. Sci. 93:185-196.

Pearce, S. C., M. V. Sanz-Fernandez, J. Torrison, M. E. Wilson, L. H. Baumgard, and N. K. Gabler. 2015. Dietary zinc attenuates heatstress induced changes in intestinal integrity and metabolism. J. Anim. Sci. 93:4702-4713.

Prasad, A. S. 2008. Zinc in human health: Effect of zinc on immune cells. Mol. Med. 14:353-357.

Prasad, A. S. 2012. Discovery of human zinc deficiency: 50 year later. J. Trace Elem. Med. Biol. 26:66-69.

Roberts, E. S., E. van Heugten, K. Lloyd, G. W. Almond, and J. W. Spears. 2002. Dietary zinc effects on growth performance and immune response of endotoxemic growing pigs. Asian-australas. J. Anim. Sci. 15:1496-1501.

Rothman, K. J. 1990. No adjustments are needed for multiple comparisons. Epidemiology 1:43-46.

Sanz Fernandez, M. V., S. C. Pearce, N. K. Gabler, J. F. Patience, M. E. Wilson, M. T. Socha, J. L. Torrison, R. Rhoads, and L. H. Baumgard. 2014. Effects of supplemental zinc amino acid complex on gut integrity in heat-stressed growing pigs. Animal 8:43-50.

Shennan, D. B., and M. Peaker. 2000. Transport of milk constituents by the mammary gland. Physiol. Rev. 80:925-951.

Shuster, D. E., R. J. Harmon, J. A. Jackson, and R. W. Hemken. 1991 Reduced lactational performance following intravenous endotoxin administration to dairy cows. J. Dairy Sci. 74:3407-3411.

Skarnes, R. C., and L. C. Chedid. 1964. Biological degraduation and inactivation of endotoxin (chromate-labeled). Pages 575-587 in Bacterial Endotoxins. M. Landy and W. Braun, ed. Rutgers University Press, New Brunswick, NJ.

Slepchenko, K. G., C. B. L. James, and Y. V. Li. 2013. Inhibitory effect of zinc on glucose-stimulated zinc/insulin secretion in an insulin-secreting $\beta$-cell line. Exp. Physiol. 98:1301-1311.

Snavely, M. D., M. G. Ziegler, and P. A. Insel. 1985. Subtype-selective down-regulation of rat renal cortical alpha- and beta-adrenergic receptors by catecholamines. Endocrinology 117:2182-2189.

Sohn, E. J., M. J. Paape, E. E. Connor, D. D. Bannerman, R. H. Fetterer, and R. R. Peters. 2007. Bacterial lipopolysaccharide stimulates bovine neutrophil production of TNF- $\alpha$, IL-1 $1 \beta$, IL-12 and IFN- $\gamma$. Vet. Res. 38:809-818.

Spears, J. W. 1989. Zinc methionine for ruminants: Relative bioavailability of zinc in lambs and effects on growth and performance of growing heifers. J. Anim. Sci. 67:835-843.

Spitzer, J. A., K. M. Nelson, and R. E. Fish. 1985. Time course of changes in gluconeogenesis from various precursors in chronically endotoxemic rats. Metabolism 34:842-849.
Takeyama, N., Y. Itoh, Y. Kitazawa, and T. Tanaka. 1990. Altered hepatic mitochondrial fatty acid oxidation and ketogenesis in endotoxic rats. Am. J. Physiol. 259:E498-E505.

Tennant, B., M. Reina-Guerra, and D. Harrold. 1973. Metabolic response of calves following acute experimental endotoxemia. Ann. Res. Vet. 4:135-147.

Toribio, R. E., C. W. Kohn, J. Hardy, and T. J. Rosol. 2005. Alterations in serum parathyroid hormone and electrolyte concentrations and urinary excretion of electrolytes in horses with induced endotoxemia. J. Vet. Intern. Med. 19:223-231.

Trevisi, E., and A. Minuti. 2018. Assessment of the innate immune response in the periparturient cow. Res. Vet. Sci. 116:47-54.

Van Eeden, S., R. Miyagashima, L. Haley, and J. C. Hogg. 1995. L-Selectin expression increases on peripheral blood polymorphonuclear leukocytes during active marrow release. Am. J. Respir. Crit. Care Med. 151:500-507.

van Miert, A. S., and J. Frens. 1968. The reaction of different animal species to bacterial pyrogens. Zentralbl. Veterinarmed. A 15:532543.

Verheijden, J. H., A. S. Van Miert, A. J. Schotman, and C. T. Van Duin. 1983. Pathophysiological aspects of E. coli mastitis in ruminants. Vet. Res. Commun. 7:229-236.

Waggoner, J. W., C. A. Loest, J. L. Turner, C. P. Mathis, and D. M. Hallford. 2009. Effects of dietary protein and bacterial lipopolysaccharide infusion on nitrogen metabolism and hormonal responses of growing beef steers. J. Anim. Sci. 87:3656-3668.

Waldron, M. R., T. Nishida, B. J. Nonnecke, and T. R. Overton. 2003. Effect of lipopolysaccharide on indices of peripheral and hepatic metabolism in lactating cows. J. Dairy Sci. 86:3447-3459.

Wellnitz, O., C. Zbinden, X. Huang, and R. M. Bruckmaier. 2016. Short communication: Differential loss of bovine mammary epithelial barrier integrity in response to lipopolysaccharide and lipoteichoic acid. J. Dairy Sci. 99:4851-4856.

Weng, X., A. P. A. Monteiro, J. Guo, C. Li, R. M. Orellana, T. N. Marins, J. K. Bernard, D. J. Tomlinson, J. M. DeFrain, S. E. Wohlgemuth, and S. Tao. 2018. Effects of heat stress and dietary zinc source on performance and mammary epithelial integrity of lactating dairy cows. J. Dairy Sci. 101:2617-2630.

Wessels, I., and R. J. Cousins. 2015. Zinc dyshomeostasis during polymicrobial sepsis in mice involves zinc transporter ZIP14 and can be overcome by zinc supplementation. Am. J. Physiol. Gastrointest. Liver Physiol. 309:G768-G778.

Wessels, I., M. Maywald, and L. Rink. 2017. Zinc as a gatekeeper of immune function. Nutrients 9:1286.

Yagi, Y., H. Shiono, T. Shibahara, Y. Chikayama, I. Nakamura, and A. Ohnuma. 2002. Increase in apoptotic polymorphonuclear neutrophils in peripheral blood after intramammary infusion of Escherichia coli lipopolysaccharide. Vet. Immunol. Imunopathol. $89: 115-125$

Zarrin, M., O. Wellnitz, H. A. van Dorland, J. J. Gross, and R. M. Bruckmaier. 2014. Hyperketonemia during lipopolysaccharide-induced mastitis affects systemic and local intramammary metabolism in dairy cows. J. Dairy Sci. 97:3531-3541.

\section{ORCIDS}

H. A. Ramirez Ramirez $\odot$ https://orcid.org/0000-0002-5074-9277

L. H. Baumgard (ㄴ) https://orcid.org/0000-0002-3077-5996 